\title{
Accelerated Barrier Repair in Human Skin Explants Induced with a Plant-Derived PPAR- $\alpha$ Activating Complex via Cooperative Interactions
}

\author{
George Majewski $\mathbb{D}^{1,2}$ \\ John Craw (1D) \\ Timothy Falla' \\ 'Rodan \& Fields, San Francisco, CA, \\ 94105, USA; ${ }^{2}$ Present Affiliation: \\ Contrast Product Development, Walnut, \\ CA, 91789, USA
}

Background: Peroxisome proliferator-activated receptors (PPARs) govern epidermal lipid synthesis and metabolism. In skin, PPAR activation has been shown to regulate genes responsible for permeability barrier homeostasis, epidermal differentiation, lipid biosynthesis, and inflammation.

Objective: Given the known dermatologic benefits of PPARs, we set out to discover a naturally derived, multi-molecule complex that would be superior to the more commonly formulated conjugated linoleic acids (CLAs). We hypothesized that a complex may be capable of modulating PPAR- $\alpha$ by cooperative or multi-ligand binding interactions to accelerate skin barrier repair.

Methods: To achieve this, we assembled a novel PPAR- $\alpha$ agonist complex, referred to as RFV3, from a combination of small molecules routinely used in Ayurvedic medicine and accepted in cosmetic and topical over-the-counter dermatologic products. We tested RFV3's potential as a PPAR- $\alpha$ agonist by evaluating its transcriptional response, ligand binding affinity to PPAR- $\alpha$, gene expression profiles and barrier repair properties in human skin explant models.

Results: We assembled RFV3 by solubilizing two standardized plant extracts in a suitable solvent and induced a significant transcriptional response in PPAR- $\alpha$ luciferase reporter assay. Furthermore, transcriptome profiling of RFV3-treated epidermal substitutes revealed expressed genes consistent with known targets of PPAR- $\alpha$, including those involved in epidermal barrier repair. In addition, in silico modeling demonstrated differential cobinding affinities of RFV3 to PPAR- $\alpha$ compared with those of the endogenous ligands (CLAs) and a synthetic PPAR- $\alpha$ agonist. Lastly, delipidated skin explant models confirmed accelerated barrier repair activity with significant increases in ceramides, filaggrin and transglutaminase-1 after treatment.

Conclusion: These findings suggest that the RFV3 complex successfully mimics a PPAR- $\alpha$ agonist and induces synthesis of skin barrier lipids and proteins consistent with known PPAR pathways.

Keywords: PPAR- $\alpha$, cooperative binding, epidermal barrier, explants, ceramides

\section{Introduction}

Nuclear receptors (NRs) are ligand-binding transcription factors that sense the cellular environment and subsequently reprogram gene expression in target tissues to coordinate the appropriate physiologic response. ${ }^{1,2}$ Upon ligand binding, NRs translocate to the nucleus, heterodimerize to their binding partner and bind to NR response elements to regulate the transcription of target genes. ${ }^{3}$ The peroxisome
Correspondence: John Craw

Rodan \& Fields, 60 Spear Street, Suite 600, San Francisco, CA, 94105, USA

Email scraw@rodanandfields.com 
proliferator-activated receptor (PPAR) family of NRs are activated by lipid metabolites and regulate a wide variety of lipid-related genes. ${ }^{4}$ There are three known PPAR isotypes: PPAR- $\alpha$, PPAR- $\beta / \delta$, and PPAR- $\gamma$. Although they share considerable sequence and structural homology, their tissue distribution, ligand specificity, and physiologic responses to ligands are unique to each isotype. All three isotypes play important roles in skin homeostasis and have been identified in different skin cell types and expressed in keratinocytes, hair follicle epithelial cells, melanocytes, immature epidermal Langerhans cells, basal and differentiated sebocytes, and cutaneous immune cells. ${ }^{5-21}$

The pivotal role of PPAR signaling in the skin has been highlighted in a multitude of studies. PPAR- $\alpha$ activators induce keratinocyte differentiation and epidermal lipid synthesis, including ceramide production, thus accelerating the morphologic and functional maturation of the epidermal permeability barrier. ${ }^{22-27}$ The epidermal barrier (EB) is localized to the outermost layer of the epidermis, the stratum corneum (SC), and maintains water content, electrolyte balance and prevents dehydration. ${ }^{28}$ The proper functioning of the EB is greatly dependent on the structure and composition of the SC. The SC is comprised of anucleated terminally differentiated keratinocytes embedded in a lamellar lipid matrix and provides a barrier to the movement of water and electrolytes. As keratinocytes differentiate to form the SC, they sequentially express specific proteins including keratins, filaggrin, transglutaminase, involucrin and loricrin that serve as important structural scaffolds for the extracellular lipid matrix. $^{29-32}$ Moreover, these proteins are also targets of PPAR activation. ${ }^{5-31}$ In addition, the differentiating keratinocytes secrete ceramides, the predominant lipid species in the extracellular matrix, which is indispensable for normal permeability function. ${ }^{33,34}$ This highly organized and orchestrated first-line of defence protects against dehydration and maintains healthy skin. Thus, lipid metabolites that activate this PPAR pathway can serve as unique regulators of EB homeostasis.

Not surprisingly, degradative changes in components of the EB are often seen in aging skin and skin diseases like psoriasis and atopic dermatitis. ${ }^{34}$ PPAR modulators have been shown to be an effective treatment strategy for these and other skin conditions. ${ }^{35}$ Systemic application of PPAR- $\gamma$ ligands decrease the growth of melanoma cells in vitro, reduce clinical symptoms of atopic dermatitis and improve psoriasis skin lesions in humans. ${ }^{36-45}$ Recent advances in PPAR agonist applications have focused on improving the skin barrier function via increased ceramide synthesis. An oat oil extract, formulated into a commercially available eczema skin care product, successfully activated PPAR- $\alpha$ and PPAR $-\beta / \delta$ to stimulate keratinocyte differentiation and ceramide synthesis. ${ }^{46}$ A topically applied hydroxy stearic acid has also been shown to be a PPAR- $\alpha$ agonist stimulating collagen in vitro, improving skin barrier function, and diminishing age spots and pores. ${ }^{47}$ Another PPAR- $\alpha$ agonist, Wy14643, significantly increased ceramide and cholesterol ester levels in reconstructed epidermis. ${ }^{48}$ Finally, strawberry seed extract and its major component tiliroside, a PPAR agonist, was recently shown to enhance the expression of glucosylceramide and $\beta$-glucocerebrosidase, and promote ceramide synthesis in the SC of human epidermal equivalents. $^{49}$

Despite these examples, PPAR modulators are still not widely used in daily skin care products for several reasons including a) inherent limitations of formulating with PPAR modulators including issues associated with solubility, oxidative stability, formulation compatibility and delivery, b) the cost and regulatory barriers associated with developing new and novel synthetic compounds c) the regulatory limitation for making product claims in non-drug skin care products.

To address these issues, we set out to design a new ligand that could activate PPAR- $\alpha$ and promote the expression of skin barrier lipids and proteins. Typically, PPARs bind with a range of lipophilic acids in their ligand binding domain (LBD), such as omega-3 fatty acids, and have been shown to be activated by a mixture of naturally occurring dietary conjugated linoleic acid (CLA) and their derivatives. ${ }^{50-52}$ To support our interpretation of the experimental data in silico molecular modeling techniques which can identify and characterize ligand binding activity and ligand-receptor interactions in the LBD with a high degree of precision was utilized. ${ }^{53}$

Historically ligand-PPAR interactions were believed to involve single molecule ligands, however research published in 2018 demonstrated that cooperative co-binding can occur between synthetic ligands and natural/endogenous ligands. In these interactions, endogenous ligands are displaced into functionally important sub-pockets of the PPAR cavity. ${ }^{54}$ In another example, a single large synthetic compound able to occupy the entire cavity has been shown to elicit allosteric changes which result in full activation and enable external binding with a PPAR co-activating protein PGC- $1 \alpha^{55}$ 
Recognizing the large Y-shaped topology of the PPAR$\gamma$ LBD, researchers at Kyoto University, Japan examined the potential of several molecules to bind in a cooperative manner. ${ }^{56}$ Using a luciferase reporter assay, Ohtera et al screened a well-known synthetic irreversible agonist GW9662, in combination with a number of plant-derived cinnamic acid derivatives to examine the potential for cooperative activation of PPAR- $\gamma$. The combination found to be the most potent activator was then linked covalently to produce a single new highly potent synthetic ligand. Docking studies were used to further elucidate how such molecules bind to the PPAR- $\gamma$ LBD. Similar results have been found by Kawabara et al who have shown that PPAR receptors can accommodate flexible $\alpha$-substituted phenylpropanoic acids, molecules structurally similar to cinnamic acid. ${ }^{57}$

Our approach was to design a PPAR complex using a unique combination of naturally derived, but readily available cosmetic-grade botanical extracts well-known to Ayurvedic medicine. The complex is designed to mimic the behavior of known synthetic PPAR agonists, while avoiding or solving typical cosmetic formulation limitations. Four ingredients (plant extract standardized in trans-pterostilbene (P90), plant extract standardized in xymenynic acid (XA), and a mixture of glyceryl linoleate/ glyceryl linolenate esters (GLGL) were combined into a single material and designated as RFV3. Standard molecular biology techniques were used to characterize the complexes' role as a PPAR- $\alpha$ agonist, primarily in terms of its transcriptional response and ability to interact with the PPAR- $\alpha$ LBD. Furthermore, since PPAR activation has been shown to normalize epidermal homeostasis in barrier disrupted skin, we investigated its effects on delipidated skin. ${ }^{5}$ We hypothesized that the individual components of RFV3 bind to the PPAR- $\alpha$ LBD in a cooperative manner eliciting PPAR-related metabolism which can accelerate barrier repair in a human skin explants model.

\section{Materials and Methods Preparation of the RFV3 Complex}

Unlike the traditional approach of synthesizing new compounds and screening for PPAR agonist activity, we instituted a rapid-design approach, identifying and blending/ solubilizing readily available compounds which are commonly used in topical dermatologic products. This approach involved the selection of existing plantderived materials with an established supply and known safety and quality standards. We began by identifying materials including several stilbenes, such as pterostilbene, which have been previously studied for PPAR- $\alpha$ agonism, and sandalwood seed oil. ${ }^{58}$ Stilbenes occur in plants through the phytoalexin biosynthetic pathway which utilizes cinnamic acid as an intermediate. ${ }^{59}$ Sandalwood seed oil has a particularly interesting composition containing an acetylenic fatty acid, XA, which has been studied for various skin protective and antiinflammatory applications. ${ }^{60-63}$

We selected Pterocarpus marsupium bark extract standardized to not less than $90 \%$ trans-pterostilbene (P90), and a Santalum album extract standardized to not less than 98\% XA. Several key elements were considered when selecting an appropriate solvent to solubilize the plant extract solids at room temperature. We considered solvents that would maximize topical delivery, ensure consistent quality and ensure good chemical and formula stability during manufacturing. It is important to note the antioxidant activity of pterostilbene was first demonstrated in vitro by its inhibition of methyl linoleate oxidation. ${ }^{64}$

A final composition for RFV3 was identified near the maximum solubility of two plant-extracted solutes, P90 and XA in the GLGL solvent mixture. The ratio by weight of solutes and solvents was 3\% Pterocarpus marsupium bark extract, 7\% Santalum album extract, and 90\% GLGL solvent blend. The RFV3 ingredients were charged to a kettle under a nitrogen blanket, heated to $65^{\circ} \mathrm{C}-70^{\circ} \mathrm{C}$ and held for 1 hour with slow propeller agitation. The mixture was then cooled to room temperature and discharged via 10-micron filter into a glass jar for storage and stability observations. A lipo-oxygen radical absorbance capacity (ORAC) test was conducted to confirm the mixture had maintained a significant ORAC after heating which was expected from the polyphenolic stilbene antioxidant. The assembled RFV3 complex produced a lipo-ORAC of $400 \mu$ moles TE/g.

\section{In vitro Analysis}

For comparative in vitro studies, the following commercially available materials were used:

- GW590735 (CAS \# 622402-22-6) PPAR- $\alpha$ agonist positive control supplied in the PPAR- $\alpha$ luciferase reporter assay kit produced by Indigo Biosciences, State College, PA, Cat. \# IB00111-32.

- Mixed CLAs (trade name Vitamin F Forte) sourced as a commercial-grade safflower oil extraction 
sample of polyunsaturated essential free fatty acids (C18:2 CLAs) with a high content of linoleic acid in its natural form (cis-9, cis-12, along with cis-9, trans11 and trans-10, cis-12), obtained from the laboratory of Dr Kurt Richter GmbH, Berlin, Germany, termed VFF.

- Glycerol esters of CLA (trade name Vitamin F glycerol ester CLR) sourced as a mixture of $>50 \%$ Glyceryl Linoleate and 5-10\% Glyceryl Linolenate, obtained from the laboratory of Dr Kurt Richter GmbH, Berlin, Germany, termed GLGL.

- Trans-pterostilbene (trade name Pterowhite ${ }^{\circledR}$ 90\%) sourced as $\geq 90 \%$ standardized extract of Pterocarpus marsupium, obtained from Sabinsa Corporation, 20 Lake Drive, East Windsor, NJ 08520, USA, termed P90.

- Xymenynic acid sourced as $\geq 98 \%$ standardized extract of Santalum album, obtained from Sabinsa Corporation, 20 Lake Drive, East Windsor, NJ 08520, USA, termed XA.

The PPAR- $\alpha$ luciferase reporter assay (Indigo Biosciences, State College, PA, Cat. \# IB00111-32, Technical Manual version 7.2) utilized Chinese Hamster Ovary (CHO) cells that have a luciferase reporter gene functionally linked to a PPAR- $\alpha$ response element. Thus, quantifying changes in luciferase expression in treated reporter cells is a surrogate measure of the changes in PPAR- $\alpha$ activity. Test materials (P90, Lot\# H140770, GLGL, Lot\# 3180325, XA, Lot\# S180156, RFV3 blend, Lot\# 030419-A, RFV3 blend, Lot\# 021219-A, and VFF Lot\# 3180062) were diluted in dimethyl sulfoxide (DMSO) at $100 \mathrm{mg} / \mathrm{mL}$ and then tested at 2 concentrations $(500 \mu \mathrm{g} / \mathrm{mL}$ and $250 \mu \mathrm{g} / \mathrm{mL})$ in triplicates on the reporter cells. GW590735 (CAS \# 62240222-6) at $300 \mathrm{nmol}$ was used as the positive control. Briefly, $200 \mu \mathrm{L}$ of reporter cells was dispensed into wells of the assay plate and pre-incubated for 4-6 hours. Following the pre-incubation period, culture media was discarded and $200 \mu \mathrm{L} /$ well of the prepared treatment media was added. After about 20 hours, the treatment media was discarded, and Luciferase Detection Reagent was added. The intensity of light emission was measured in Relative Light Units (RLUs) from each assay well, quantified with Thermo Scientific Luminoskan Ascent Microplate Luminometer. This instrument passed DLReady ${ }^{\mathrm{TM}}$ validation at Promega Corporation.

To better understand the contribution of P90 in PPAR transcriptional activation within the RFV3 complex, P90 was retested at lower non-cytotoxic concentrations using the same assay. In this second assay, a comparison was made between P90 and RFV3 with a delivered equivalent concentration of $10.3 \mu \mathrm{M}$ of trans-pterostilbene by testing $3.0 \mu \mathrm{g} / \mathrm{mL}$ of P90, against $100 \mu \mathrm{g} / \mathrm{mL}$ of RFV3.

Statistically significant variation was defined as $\geq 20 \%$ variation from the water control with a p-value $<0.05$ calculated using double-tailed $t$ test.

\section{Gene Expression Analysis}

In order to assess whether RFV3-treated epidermis-like cells were able to express PPAR- $\alpha$ target genes, RNA extracted from these cells was reverse transcribed to DNA, and polymerase chain reaction (PCR) assays were performed using a panel of 96 selected genes that included PPAR- $\alpha$ target genes and control housekeeping genes. Epidermal tissue substitutes (cat. \# 102-3D-12; Lot\# 2744) were obtained from Cell Applications (San Diego, $\mathrm{Ca})$. They were prepared in vitro in culture plate inserts from neonatal keratinocytes and fibroblasts and differentiated over a period of about two weeks into stratified squamous epithelium. Such 3D cultures approximate human epidermis and are commonly used in skin aging research. Tissues were equilibrated in a cell culture incubator for 60 minutes and were then exposed to RFV3 at $2 \% \mathrm{v} / \mathrm{v}$ (diluted in glycerin), and to the negative control (glycerin) in triplicates for 24 hours.

Real-time quantitative (q) PCR tests were conducted at the end of the incubation. Tissues were rinsed and RNA was extracted and purified with NucleoSpin RNA kit from Macherey-Nagel (cat. \# 740955.240C; Bethlehem, PA), using QiaCibe robotic station (Qiagen, Germantown, MD). Purified total RNA was assessed for purity at 260 $\mathrm{nm}$ and $280 \mathrm{~nm}\left(\mathrm{~A}_{260} / \mathrm{A}_{280}>1.7\right)$ with NanoDrop Lite (Thermo Fisher Scientific, Waltham, MA). Pure samples with $\mathrm{A}_{260} / \mathrm{A}_{280}$ of $>1.7$ were standardized and the expression of the panel of genes of interest was quantified by qPCR with BioRad iCycler iQ Detection System using primers from Realtimeprimers (RTP; Elkins Park, PA), 5XAll-In-One $1^{\text {st }}$ Strand cDNA Synthesis Mix (cat. \# 4375; Azura Genomics/RTP). Efficiency $\Delta \Delta \mathrm{Ct}$ method was used for quantification of results, after the normalization of gene expression to eight housekeeping genes (ACTB, B2M, GAPDH, GUSB, HPRT1, PGK1, PP1A, RPL13A). Genes were considered differentially expressed if the level of expression was reasonably high $(\leq 30$ cycles to detect), p-value was $<0.05$ and the modulation (fold change) was $\geq 2$. 
To further identify pathways and molecular functions common to the genes observed by PCR analysis, String database software was used to examine protein functional connectivity.

\section{In silico Modeling}

In silico analysis was used to study the docking of RFV3's four component molecules individually, and as combinations. The test materials were modeled to ascertain binding energies and configurations to the LBD of PPAR- $\alpha$, using GW590735 (identified as GW-735469 in the PDB ID: 2P54 crystal structure) as a "positive control" for conformational analysis.

The X-ray crystal structure of the target receptor PPAR- $\alpha$ (PDB ID: 2P54, Resolution 1.79 A) was selected for the study based on its resolution and was downloaded from Protein Data Bank. ${ }^{65}$ The 3D structure of PPAR- $\alpha$ (PDB ID: 2P54) bound with SRC1 peptide and GW590735 was taken as the known PPAR- $\alpha$ activator for defining active sites. Conjugated linoleic acid, cis-9, trans-11, trans-10, cis- 12 , and cis- 9 , cis- 12 were used as the standard compounds. The test set compounds consisted of 4 compounds, glyceryl linoleate, glyceryl linolenate, trans pterostilbene, and xymenynic acid, and 11 combinations of the four compounds. Structures of these compounds were obtained from PubChem.

The X-ray crystal structure of PPAR- $\alpha$ (PDB ID: 2P54), after simplification and optimization, was defined as the target macromolecule in Autodock Vina Wizard of PyRx version 0.8 software. 3D structures of the standard compounds, CLA: cis-9, trans-11, trans-10, cis-12 and cis9, cis-12 were optimized in Discovery Studio Visualizer version 2.5 software and used for docking using PyRx version 0.8 . The test set of the four ligands was structurally optimized in Discovery Studio Visualizer version 2.5 software for docking using PyRx version 0.8 software. Combination of the four compounds $(\mathrm{N}=4, \mathrm{r}=2 ; \mathrm{N}=$ $4, r=3 ; N=4, r=4$ ) were modelled resulting in a total of 11 combinations.

The active site analysis was done by calculating $\mathrm{x}$, $y$ and $z$ co-ordinates of GW590735 in the PyRx version 0.8 software for PPAR- $\alpha$. Molecular docking was performed in the workspace of PyRx version 0.8 software through inbuilt Autodock Vina Wizard. Docking was performed on default parameters of number of generation and energy evaluation for 10 steps of each run. The predicted binding affinity was calculated in $\mathrm{kcal} / \mathrm{mol}$. Multiple ligand docking may affect the binding affinity and conformation of the compounds; therefore, to analyze the effect of combination of compounds on binding affinity, a protocol was used. In the protocol, a single ligand was docked with PPAR- $\alpha$ and the complex of PPAR- $\alpha$ and ligand was used as a target for the next ligand. In this case, we used cis- 9 , trans- 11 and a redocking simulation on a fixed parameter to evaluate the validity and accuracy of the system. We superimposed all docked poses of cis-9, trans-11 on the initial docked pose and then calculated root-mean-square deviation (RMSD) in Discovery Studio Visualizer version 2.5 Software that showed zero root mean square deviation.

\section{Ex vivo Delipidated Explants}

Three dilutions of RFV3 complex in Caprylic/Capric Triglyceride (CCT, BASF Mytriol ${ }^{\circledR} 318$ ) at $0.5,3,5 \%$ by weight were prepared.

The ex vivo studies were performed on skin tissue obtained from surgical residues collected in line with the Declaration of Helsinki and article L.1243-4 of the French Public Health Code. The latter does not require any prior authorization by an ethics committee for sampling and using surgical wastes, however all tissue was collected under an ethically approved protocol and/or project and/ or programme, with appropriate written informed consent freely given by the tissue donors. The ex vivo tissue studies were conducted in the spirit of the Good Laboratory Practices.

Sixty-six explants of an average diameter of $11 \mathrm{~mm}$ $( \pm 1 \mathrm{~mm})$ obtained after an abdominoplasty from a 54-yearold Caucasian woman (P2129-AB54) with a type II phototype, were prepared. The explants were placed in BEM culture medium (BIO-EC's Explants Medium) at $37^{\circ} \mathrm{C}$ in a humid, $5 \% \mathrm{CO}_{2}$ atmosphere.

On day 0 , a section of the abdominoplasty was delipidated by applying a 1:1 (v:v) mixture of ether:acetone for 2 minutes, two times, followed by wiping the skin surface with a paper tissue. On this delipidated area, 33 skin explants termed " $D$ " of an average diameter of $11 \mathrm{~mm}$ $( \pm 1 \mathrm{~mm})$ were prepared as described before. Total explant distribution in this study included 42 explants. The 33 delipidated explants and 9 un-delipidated explant controls were designated to studying the effects of RFV3 on barrier repair markers are presented in Table 1 . The remaining 24 un-delipidated explants were dedicated to other endpoints and will be reported upon at a later date.

On day 0 , just after delipidation, $\mathrm{D}(0.5 \% \mathrm{RFV} 3), \mathrm{D}(3 \%$ RFV3), $\mathrm{D}(5 \%$ RFV3) and the placebo $\mathrm{D}(\mathrm{E})$ were topically 
Table I Explant Distribution Designated to Study RFV3 for Barrier Repair Properties

\begin{tabular}{|c|c|c|c|c|}
\hline Batch & Destination & Treatment & No. of Explants & Sampling Time \\
\hline $\mathrm{U}(\mathrm{C}) 0$ & Untreated (control) & - & 3 & Day 0 \\
\hline $\mathrm{D}(\mathrm{C}) 0$ & Delipidated (control) & Delipidation & 3 & Day 0 \\
\hline $\mathrm{U}(\mathrm{C})$ & Untreated (control) & - & 6 & $\begin{array}{l}\text { Day } 0+3 \mathrm{~h} \\
\text { Dayl }(24 \mathrm{hr})\end{array}$ \\
\hline$D(C)$ & Delipidated (control) & Delipidation & 6 & $\begin{array}{l}\text { Day } 0+3 \mathrm{~h} \\
\text { Dayl }(24 \mathrm{hr})\end{array}$ \\
\hline$D(E)$ & Delipidated (excipient treated) & Delipidation + Excipient & 6 & $\begin{array}{l}\text { Day } 0+3 \mathrm{~h} \\
\text { Dayl }(24 \mathrm{hr})\end{array}$ \\
\hline $\mathrm{D}(0.5 \% \mathrm{RFV} 3)$ & Delipidated ( $0.5 \%$ RFV3 treated) & Delipidation + Excipient $+0.5 \%$ RFV3 & 6 & $\begin{array}{l}\text { Day } 0+3 \mathrm{~h} \\
\text { Dayl }(24 \mathrm{hr})\end{array}$ \\
\hline $\mathrm{D}(3 \% \mathrm{RFV} 3)$ & Delipidated (3\% RFV3 treated) & Delipidation + Excipient $+3 \%$ RFV3 & 6 & $\begin{array}{l}\text { Day } 0+3 \mathrm{~h} \\
\text { Dayl }(24 \mathrm{hr})\end{array}$ \\
\hline D(5\%RFV3) & Delipidated (5\% RFV3 treated) & Delipidation + Excipient + 5\%RFV3 & 6 & $\begin{array}{l}\text { Day } 0+3 \mathrm{~h} \\
\text { Dayl }(24 \mathrm{hr})\end{array}$ \\
\hline
\end{tabular}

applied at $2 \mu \mathrm{L}$ per explant $\left(2 \mathrm{mg} / \mathrm{cm}^{2}\right)$ and spread using a small spatula. The control explants $U(C)$ did not receive any treatment.

On day 0,3 explants from the batch $\mathrm{U}(\mathrm{C}) 0$ and $\mathrm{D}(\mathrm{C}) 0$ (just after delipidation) were collected and cut into two parts. Half of these were fixed in buffered formalin solution and the other half were frozen at $-80^{\circ} \mathrm{C}$. On day $0+3 \mathrm{~h}$ ( $3 \mathrm{~h}$ after delipidation) and day 1 ( $24 \mathrm{~h}$ after delipidation), 3 explants from each batch were collected and processed similar to $\mathrm{U}(\mathrm{C}) 0$.

Histological processing was performed after fixation for 24 hours in buffered formalin. The samples were dehydrated and impregnated in paraffin using a Leica PEARL dehydration automat. The samples were embedded using a Leica EG 1160 embedding station. 5- $\mu$ m-thick sections were cut using a Leica RM 2125 Minot-type microtome, and the sections were mounted on Superfrost ${ }^{\circledR}$ histological glass slides.

Frozen samples were cut at $7-\mu \mathrm{m}$ thickness with a Leica CM 3050 cryostat. The sections were then mounted on silanized glass slides Superfrost ${ }^{\circledR}$ Plus.

Alterations in tissue and cell morphology of the epidermal and dermal structures was assessed using paraffinized sections after Masson's trichrome staining, Goldner variant. The staining was assessed by microscopy for all batches (Olympus BX43 microscope). Changes in morphology were graded and compared to the baseline untreated control day 0 explant $(\mathrm{U}(\mathrm{C}) 0)$ as follows: $\mathrm{G}=$ good, FG = fairly good, VSA = very slightly altered, $\mathrm{SA}=$ slightly altered, $\mathrm{MA}=$ moderately altered, $\mathrm{FCA}=$ fairly clearly altered, $\mathrm{CA}=$ clearly altered, $\mathrm{VCA}=$ very clearly altered.

Formalin-fixed paraffin-embedded sections were incubated with primary antibodies, including a monoclonal anti-ceramide antibody (1:25, Glycobiotech, ref. MAB_0013, clone S58-9), a monoclonal anti-filaggrin antibody (1:1000, Santa Cruz, ref. sc-66192, clone AKH1), and a polyclonal anti-transglutaminase (TGM-1) antibody (1:100, Novus biologicals, ref. NB100-1844), diluted in PBS, BSA $0.3 \%$, and Tween $20(0.05 \%)$ for 1 hour at room temperature. The slides for ceramide and TGM1, were amplified with secondary antibodies (biotin/ streptavidin). These were detected by VIP, a violet substrate of peroxidase (Vector, ref. PK-7200) for ceramide and TGM-1. Filaggrin was detected by Alexa Fluor 488 (Life Technologies, ref. A11001), and the nuclei were counterstained with propidium iodide. Immunostaining was performed for all batches using an automated slideprocessing system (Dako, AutostainerPlus) and was assessed by microscopy (Leica DMLB and/or Olympus BX43).

Image analysis was performed on all images for each batch with a numeric DP72 Olympus camera using the cell $\wedge$ D Software (Olympus, Rungis, France) for each batch of explants, the percentage of the region of interest covered by the staining (stained surface percentage) was 
determined by image analysis. First, the schematic representation of the immunostained image to be analyzed was captured and stained in green. Pixel selection corresponding to the green image was performed with a yellow mask. The region of interest was then determined with a red mask. Pixels common to the red and yellow masks were combined to select the region of interest. The surfaces of the red and purple masks were measured to then calculate the percentage of the surface covered by the staining. The stained surface percentage for each treatment was compared to the untreated condition. Similar comparisons were made for the delipidated batches with or without treatment.

In order to condense data, our histological observations are not presented in this manuscript other than noting the 3-hour observations in the results section. Complete findings of our immunostaining image analysis are presented by processing nine images ( 3 for each explant) for each target (ceramides, filaggrin, transglutaminase-1). Analyzed explant batches included day 1: $\mathrm{U}(\mathrm{C}), \mathrm{D}(\mathrm{C}), \mathrm{D}(\mathrm{E}), \mathrm{D}(0.5 \% \mathrm{RFV} 3), \mathrm{D}(3 \%$ RFV3), D(5\%RFV3) which is (6 batches, 3 explants/batch, thus a total of 18 explants) 54 images per target. Three controls represented untreated, delipidated treated, delipidated treated + excipient treated were designated as $\mathrm{U}(\mathrm{C}), \mathrm{D}(\mathrm{C}), \mathrm{D}(\mathrm{E})$, respectively. The data from each experiment were analyzed statistically by Student's $t$-test. Data are expressed as mean \pm SD. $p \leq 0.05$ was considered statistically significant.

\section{Results}

\section{In vitro Analysis}

Individual components and the RFV3 complex were tested for PPAR- $\alpha$ activity in vitro and compared against commonly formulated endogenous ligands (CLAs) utilizing a luciferase reporter gene assay. VFF, XA and RFV3 were able to transcriptionally activate the luciferase reporter gene under the PPAR- $\alpha$-controlled promoter (Figure 1).

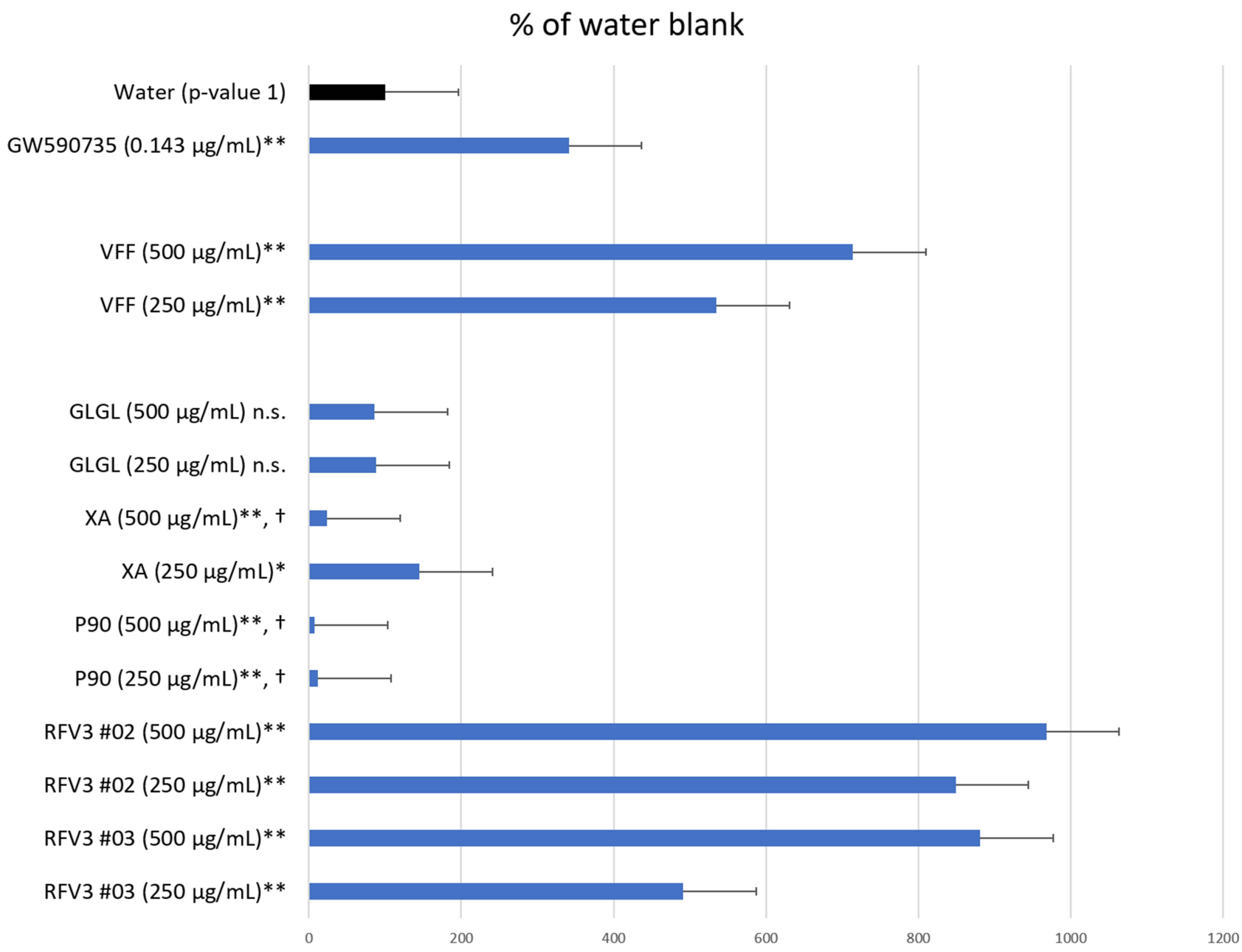

Figure I Degree of PPAR- $\alpha$ transcription activation induced by test materials depicted by the Reporter Assay System. Data are presented as mean value \pm SEM, $\mathrm{n}=\mathrm{I} 3$ for water, $n=3$ for test samples; ${ }^{*} \mathrm{p}$-value $<0.05$, ${ }^{* *} \mathrm{p}$-value $<0.01$, n.s. $=$ not significant, $\dagger=$ cytotoxic conditions observed. 
Table 2 Comparison of Pterocarpus Marsupium Bark Extract (P90) to RFV3 at Equivalent Concentrations of Trans-Pterostilbene I0.3 $\mu \mathrm{m}$ on the Transcriptional Response of the PPAR- $\alpha$-Controlled Luciferase Reporter Gene. Data are Presented as Mean Values, $\mathrm{n}=5$ for Water; $\mathrm{n}=6$ for Test Samples

\begin{tabular}{|l|c|c|c|c|}
\hline Test Material & Concentration $\mathbf{\mu g} \mathbf{m L}$ & Concentration $\boldsymbol{\mu M}$ (Active Constituent) & \% Control (Water) & p-value \\
\hline GW590735 & 0.143 & 0.300 & 1112 & 0.000 \\
Water & - & - & 100 & 1 \\
P90 & 3 & 10.3 (Trans pterostilbene)* $^{*}$ & 342 & 0.026 \\
RFV3 & 100 & 10.3 (Trans pterostilbene) & 602 & 0.031 \\
& & 24.9 (Xymenynic Acid)* & & \\
\hline
\end{tabular}

Note: *Calculated based on plant standardization of active compounds.

Interestingly, the RFV3 blend exhibited superior agonistic behavior for PPAR- $\alpha$ in a dose-dependent manner in comparison to VFF (endogenous ligands/CLAs) and RFV3's individual components. RFV3 did not exhibit cytotoxicity at either of the test dilutions of $250 \mu \mathrm{g} / \mathrm{mL}$ and $500 \mu \mathrm{g} /$ $\mathrm{mL}$. GLGL, a solvent utilized in preparation of RFV3, did not produce a transcriptional response and was not found to be cytotoxic. GLGL did not produce a significant result in this study; P90 induced cytotoxicity at both $250 \mu \mathrm{g} / \mathrm{mL}$ and $500 \mu \mathrm{g} / \mathrm{mL}$ test dilutions, and XA exhibited cytotoxicity at $500 \mu \mathrm{g} / \mathrm{mL}$. XA did produce a weak, yet significant, transcriptional response at the $250 \mu \mathrm{g} / \mathrm{mL}$ concentration. The positive control GW590735 at $300 \mathrm{nM}$ strongly upregulated the expression of the receptor gene validating the experiment.

The comparison of P90 to RFV3 is detailed in Table 2. Retesting P90 and RFV3 at lower concentrations yielded transcriptional responses without inducing cell culture cytotoxicity. P90 and RFV3 applied at equivalent concentrations $(10.3 \mu \mathrm{M})$ of trans-pterostilbene resulted in $342 \%$ and $602 \%$, change of luciferase expression respectively, as compared to the control (water).

\section{Gene Expression Analysis}

In a 96 plate study, gene expression in RFV3-treated cells was compared to the glycerin-treated controls, genes with negative value of FC (fold change) were downregulated in the RFV3-treated cells, while genes with positive value of FC were upregulated in the RFV3-treated cells. RFV3 demonstrated gene expression consistent with known PPAR- $\alpha$ transcriptional profiles shown in Table 3. The modulation of known PPAR-induced genes included down regulation of inflammation-related genes (TNF $\alpha$, IL-6). Gene expression related to epidermal differentiation included modulation of keratins (KRT1, KRT5, KRT6B, KRT17) and cornified envelope precursor genes LCE1D, S100A8, S100A9. Furthermore, upregulated genes involved in supporting epidermal structure, and barrier function included AQP3 (water channel), CDH1 (cell adhesion cadherin), FLG (filaggrin), CERS3 (ceramide synthase).

In this model system, RFV3 significantly modulated $17 \%$ of the genes in the tested panel. The GeneMANIA software was used to analyze the functions of these genes and observed that $57 \%$ of the modulated genes are coexpressed, indicating a robust master-regulator effect, possibly involving the PPAR and/or TGF-beta signaling cascades. In addition, String-DB analysis that predicts protein association networks showed advanced connectivity between the modulated genes, with several clusters, such as keratins, TGF-beta, TNF-alpha, and e-cadherin. (Figure 2).

\section{In silico Modeling}

PPAR- $\alpha$ (PBD ID: 2P54) contains 16 helices, 4 beta strands, 11 bends and 16 turns. ${ }^{65}$ GW590735 (a positive control and synthetic PPAR- $\alpha$ agonist) occupies the binding pocket formed by helices, bends and beta strands. The binding site of GW590735 in the ligand binding pocket of PPAR- $\alpha$ is composed of the amino acid residues CYS-275, VAL-332, CYS-276, MET-355, SER-280, TYR-314, HIS440 and TYR-464. GW590735 showed hydrogen bonding interactions with SER-280, TYR-314, HIS-440 and TYR464 through ligand explorer. ${ }^{65}$

In assessing the binding sites of the CLA isomer, cis-9, trans-11 at a distance criterion of $2.5 \AA$, the interacting amino acid residues were LYS-358, HIS-440, LEU-443, and GLU-439. We similarly assessed the other two CLA isomers, trans-10, cis-12 and cis-9, cis-12 (Table 4).

When comparing the binding site interacting residues of all three CLA isoforms with PPAR- $\alpha$, none of the common amino acid residues showed direct interactions (hydrogen bonding) and cis-9, cis-12 did not have any common binding residues with GW590735. Cis-9, trans11 and trans-10, cis-12 each shared two common residues 
Table 3 Description of 36 of 96 Significantly and Near-Significantly Modulated Genes. Fold Change vs Control for Each Gene on the PCR Panel. Modulation of Gene Expression by RFV3 vs Glycerin Negative Control Expressed as Fold Change (FC; Up- or DownRegulation)

\begin{tabular}{|c|c|c|c|}
\hline $\begin{array}{l}\text { Gene } \\
\text { Symbol }\end{array}$ & $\begin{array}{l}\text { p-value*/Average } \\
\text { Threshold Cycles }\end{array}$ & $\begin{array}{l}\text { Fold Up- or } \\
\text { Down- } \\
\text { Regulation }\end{array}$ & $\begin{array}{l}\text { RFV3 Near-Differentially and Differentially- Expressed Genes (Comments } \\
\text { and References) }\end{array}$ \\
\hline KRTI & $0.011 \neq$ & -2.6 & $\begin{array}{l}\text { Keratin, type II cytoskeletal I; Krt I participates in an inflammatory network in murine } \\
\text { keratinocytes. }^{61}\end{array}$ \\
\hline KRT5 & $0.024 \ddagger$ & 1.8 & $\begin{array}{l}\text { Keratin, type II cytoskeletal } 5 \text {; involved in proliferation and differentiation of stratified } \\
\text { epithelial cells. }{ }^{62}\end{array}$ \\
\hline KRT6B & $0.014 \neq$ & 2.1 & $\begin{array}{l}\text { Keratin, type II cytoskeletal } 6 \mathrm{~B} ; \mathrm{KRT} 6 / 16 / 17 \text { recognized as key early barrier alarmins } \\
\text { and upregulation of these keratins alters proliferation, cell adhesion, migration and } \\
\text { inflammatory features of } \mathrm{KCs} .{ }^{63}\end{array}$ \\
\hline KRTI7 & $0.000 \ddagger$ & -2.6 & $\begin{array}{l}\text { Keratin, type I cytoskeletal I7; KRT6/I6/I7 recognized as key early barrier alarmins } \\
\text { and upregulation of these keratins alters proliferation, cell adhesion, migration and } \\
\text { inflammatory features of KCs. }{ }^{63}\end{array}$ \\
\hline CASPI & $0.050 \ddagger$ & 2.0 & $\begin{array}{l}\text { Caspase-I; Thiol protease that cleaves IL-I beta between an Asp and an Ala, releasing } \\
\text { the mature cytokine which is involved in a variety of inflammatory processes. } \\
\text { Important for defence against pathogens. Can also promote apoptosis. Converting } \\
\text { enzyme involved in keratinocyte terminal differentiation and cornification. }{ }^{64}\end{array}$ \\
\hline TIMPI & $0.081 \neq$ & 2.1 & $\begin{array}{l}\text { Metalloproteinase inhibitor I; Metalloproteinase inhibitor that functions by forming } \\
\text { one to one complexes with target metalloproteinases, such as collagenases, and } \\
\text { irreversibly inactivates them by binding to their catalytic zinc cofactor. }\end{array}$ \\
\hline FGF2 & $0.007 \ddagger$ & 2.0 & $\begin{array}{l}\text { Fibroblast growth factor 2; Plays an important role in the regulation of cell survival, } \\
\text { cell division, angiogenesis, cell differentiation and cell migration. Functions as potent } \\
\text { mitogen in vitro. Can induce angiogenesis; Belongs to the heparin-binding growth } \\
\text { factors family regulatory protein in aging skin remodeling and wound healing. }\end{array}$ \\
\hline IL6 & $0.016 \neq$ & -2.5 & $\begin{array}{l}\text { Interleukin-6; Cytokine with a wide variety of biological functions. It is a potent } \\
\text { inducer of the acute phase response. Has involvement in atopic dermatitis and } \\
\text { psoriasis with interdependence to PPAR- } \alpha . .^{65,67}\end{array}$ \\
\hline SERPINEI & $0.005 \ddagger$ & 1.8 & $\begin{array}{l}\text { Plasminogen activator inhibitor I; Serine protease inhibitor. This inhibitor acts as } \\
\text { "bait" for tissue plasminogen activator, urokinase, protein C and matriptase- } 3 \text { / } \\
\text { TMPRSS7. }\end{array}$ \\
\hline FOXOI & $0.005 \ddagger$ & 1.9 & $\begin{array}{l}\text { Forkhead box protein OI; Transcription factor that is the main target of insulin } \\
\text { signalling and regulates metabolic homeostasis in response to oxidative stress. Known } \\
\text { as pro-apoptotic, keratinocyte-differentiating. }\end{array}$ \\
\hline PLAUR & $0.013 \neq$ & 2.4 & $\begin{array}{l}\text { Urokinase plasminogen activator surface receptor; Acts as a receptor for urokinase } \\
\text { plasminogen activator. Plays a role in localizing and promoting plasmin formation. } \\
\text { Possible ECM remodeling. }\end{array}$ \\
\hline HGF & $0.022 \dagger$ & -8.1 & Hepatocyte growth factor; linked to melanocyte proliferation. ${ }^{68}$ \\
\hline HSFI & $0.043 \ddagger$ & 2.3 & $\begin{array}{l}\text { Heat shock factor protein I; Function as a stress-inducible and DNA-binding } \\
\text { transcription factor that plays a central role in the transcriptional activation of the } \\
\text { heat shock response (HSR) - HSPs are known to be linked with PPAR activation }\end{array}$ \\
\hline VEGFA & $0.010 \ddagger$ & 1.6 & $\begin{array}{l}\text { Vascular endothelial growth factor A; Growth factor active in angiogenesis, vasculogenesis } \\
\text { and endothelial cell growth. Induces endothelial cell proliferation, promotes cell } \\
\text { migration, inhibits apoptosis and induces permeabilization of blood vessels. }\end{array}$ \\
\hline
\end{tabular}


Table 3 (Continued).

\begin{tabular}{|c|c|c|c|}
\hline $\begin{array}{l}\text { Gene } \\
\text { Symbol }\end{array}$ & $\begin{array}{l}\text { p-value*/Average } \\
\text { Threshold Cycles }\end{array}$ & $\begin{array}{l}\text { Fold Up- or } \\
\text { Down- } \\
\text { Regulation }\end{array}$ & $\begin{array}{l}\text { RFV3 Near-Differentially and Differentially- Expressed Genes (Comments } \\
\text { and References) }\end{array}$ \\
\hline AQP3 & $0.030 \ddagger$ & 2.4 & $\begin{array}{l}\text { Aquaporin-3; Water channel required to promote glycerol permeability and water } \\
\text { transport across cell membranes. Acts as a glycerol transporter in skin and plays an } \\
\text { important role in regulating SC (stratum corneum) and epidermal glycerol content. Involved } \\
\text { in skin hydration, wound healing, and tumorigenesis. Known to be mediated by PPAR. }{ }^{67}\end{array}$ \\
\hline $\mathrm{CDHI}$ & $0.002 \ddagger$ & 2.6 & $\begin{array}{l}\text { Cadherin-I; Cadherins are calcium-dependent cell adhesion proteins. Cadherins are } \\
\text { involved in dermal-epidermal adhesion. }\end{array}$ \\
\hline LCEID & $0.043 \ddagger$ & 2.3 & $\begin{array}{l}\text { Late cornified envelope protein ID; Precursors of the cornified envelope of the } \\
\text { stratum corneum. }\end{array}$ \\
\hline PANXI & $0.052 \ddagger$ & 2.4 & $\begin{array}{l}\text { Pannexin-I; Structural component of the gap junctions and the hemichannels. May } \\
\text { play a role as a } \mathrm{Ca}(2+) \text {-leak channel to regulate } \mathrm{ER} \mathrm{Ca}(2+) \text { homeostasis. }\end{array}$ \\
\hline PDCD6 & $0.068 \ddagger$ & 2.2 & Programmed cell death protein 6. \\
\hline CERS3 & $0.007 \ddagger$ & 1.6 & $\begin{array}{l}\text { Ceramide synthase } 3 \text {; Has (dihydro) ceramide synthesis activity with relatively broad } \\
\text { substrate specificity, but a preference for CI8:0 and other middle- to long-chain fatty } \\
\text { acyl-CoAs (By similarity). It is crucial for the synthesis of very long-chain ceramides in } \\
\text { the epidermis, to maintain epidermal lipid homeostasis and terminal differentiation. }{ }^{69} \\
\text { Ceramide synthesis is known to be mediated by PPAR. }{ }^{67}\end{array}$ \\
\hline POTI & $0.001 \neq$ & 1.9 & $\begin{array}{l}\text { Protection of telomeres protein I; Component of the telomerase ribonucleoprotein } \\
\text { (RNP) complex that is essential for the replication of chromosome termini. }\end{array}$ \\
\hline SI00A8 & $0.051 \ddagger$ & 3.3 & $\begin{array}{l}\text { Protein } \mathrm{SI00-A8;} \mathrm{SI00A8} \text { is a calcium- and zinc-binding protein which plays } \\
\text { a prominent role in the regulation of inflammatory processes and immune response. It } \\
\text { can induce neutrophil chemotaxis and adhesion. }\end{array}$ \\
\hline SI00A9 & $0.044 \ddagger$ & -2.9 & $\begin{array}{l}\text { Protein } \mathrm{SI00-A9;} \mathrm{SI00A9} \text { is a calcium- and zinc-binding protein which plays } \\
\text { a prominent role in the regulation of inflammatory processes and immune response }\end{array}$ \\
\hline SIRTI & $0.082 \ddagger$ & 1.8 & $\begin{array}{l}\text { NAD-dependent protein deacetylase sirtuin-I; NAD-dependent protein deacetylase } \\
\text { that links transcriptional regulation directly to intracellular energetics and participates } \\
\text { in the coordination of several separated cellular functions such as cell cycle, response } \\
\text { to DNA damage, metabolism, apoptosis and autophagy. Loss of sirtuin I (SIRTI) } \\
\text { disrupts skin barrier integrity and sensitizes mice to epicutaneous allergen challenge. }\end{array}$ \\
\hline SMAD2 & $0.053 \ddagger$ & 1.7 & $\begin{array}{l}\text { Mothers against decapentaplegic homolog 2; Receptor-regulated SMAD (R-SMAD) } \\
\text { that is an intracellular signal transducer and transcriptional modulator activated by } \\
\text { TGF-beta (transforming growth factor) and activin type I receptor kinases. TGF-b } \\
\text { signal transduction pathway regulator. }\end{array}$ \\
\hline TERF2 & $0.094 \ddagger$ & 1.6 & $\begin{array}{l}\text { Telomeric repeat-binding factor 2; Binds the telomeric double-stranded } 5 \text { '-TTAGGG } \\
-3^{\prime} \text { repeat and plays a central role in telomere maintenance and protection against } \\
\text { end-to-end fusion of chromosomes. }\end{array}$ \\
\hline TFAM & $0.049 \ddagger$ & 2.1 & $\begin{array}{l}\text { Transcription factor A, mitochondrial; Binds to the mitochondrial light strand } \\
\text { promoter and functions in mitochondrial transcription regulation. Mitochondrial } \\
\text { transcription factor. }\end{array}$ \\
\hline TFB2M & $0.056 \ddagger$ & 1.7 & $\begin{array}{l}\text { Dimethyladenosine transferase } 2 \text {, mitochondrial; S-adenosyl-L-methionine-dependent } \\
\text { methyltransferase which specifically dimethylates mitochondrial I } 2 \text { S rRNA at the } \\
\text { conserved stem loop. Mitochondrial transcription factor. }\end{array}$ \\
\hline
\end{tabular}

(Continued) 
Table 3 (Continued).

\begin{tabular}{|c|c|c|c|}
\hline $\begin{array}{l}\text { Gene } \\
\text { Symbol }\end{array}$ & $\begin{array}{l}\text { p-value*/Average } \\
\text { Threshold Cycles }\end{array}$ & $\begin{array}{l}\text { Fold Up- or } \\
\text { Down- } \\
\text { Regulation }\end{array}$ & $\begin{array}{l}\text { RFV3 Near-Differentially and Differentially- Expressed Genes (Comments } \\
\text { and References) }\end{array}$ \\
\hline TGFBI & $0.005 \ddagger$ & 1.8 & $\begin{array}{l}\text { Transforming growth factor beta-I; Multifunctional protein that controls proliferation, } \\
\text { differentiation and other functions in many cell types. It positively and negatively regulates } \\
\text { many other growth factors. Stimulates sustained production of collagen through the } \\
\text { activation of CREB3LI. TGFBI is a master regulator of skin anti-aging processes. }\end{array}$ \\
\hline TLR2 & $0.003 \ddagger$ & 2.9 & $\begin{array}{l}\text { Toll-like receptor 2; Co-operates with LY96 to mediate the innate immune response } \\
\text { to bacterial lipoproteins and other microbial cell wall components. }\end{array}$ \\
\hline TMEMI 35 & $0.006 \neq$ & 2.1 & $\begin{array}{l}\text { Transmembrane protein I35; Involved in mitochondrial metabolism by regulating the } \\
\text { balance between mitochondrial fusion and fission. }\end{array}$ \\
\hline TMEM33 & $0.035 \ddagger$ & 2.2 & $\begin{array}{l}\text { Transmembrane protein 33; Acts as a regulator of the tubular endoplasmic reticulum } \\
\text { (ER) network. }\end{array}$ \\
\hline TOLLIP & $0.018 \ddagger$ & 1.8 & $\begin{array}{l}\text { Toll-interacting protein; Component of the signalling pathway of IL-I and Toll-like } \\
\text { receptors. Inhibits cell activation by microbial products. }\end{array}$ \\
\hline TXNIP & $0.117 \ddagger$ & 1.3 & $\begin{array}{l}\text { Thioredoxin-interacting protein; May act as an oxidative stress mediator by inhibiting } \\
\text { thioredoxin activity or by limiting its bioavailability. }\end{array}$ \\
\hline FLG & $0.017 \ddagger$ & 2.4 & $\begin{array}{l}\text { Filaggrin; Aggregates keratin intermediate filaments and promotes disulfide-bond } \\
\text { formation among the intermediate filaments during terminal differentiation of mammalian } \\
\text { epidermis. Filaggrin is known as an essential barrier protein mediated by PPAR. }{ }^{67}\end{array}$ \\
\hline TNF & $0.011+$ & -13.7 & $\begin{array}{l}\text { Tumor necrosis factor; Cytokine that binds to TNFRSFIA/TNFRI and TNFRSFIB/ } \\
\text { TNFBR. It is mainly secreted by macrophages and can induce cell death of certain } \\
\text { tumor cell lines. Master regulator of inflammation. Linked with atopic dermatitis and } \\
\text { psoriasis. PPAR- } \alpha \text { exerting beneficial effects in atopic dermatitis. }{ }^{67}\end{array}$ \\
\hline
\end{tabular}

Notes: *p-value calculated by $t$-test calculated FRES vs glycerin negative control. $\ddagger$ expression of a particular gene was high (<30 cycles to visualize) in both control and the comparator. $\dagger$ gene's average threshold cycle was high $(>30)$ in either the control or the test sample, and was reasonably low in the other samples $(<30)$.

with GW590735 (MET-355, HIST-440; CYS-275, CYS276, respectively).

All individual RFV3 compounds $(\mathrm{r}=1)$ showed binding affinity in the range of $-6.1 \mathrm{kcal} / \mathrm{mol}$ to $-6.7 \mathrm{kcal} / \mathrm{mol}$ which were comparable to the binding affinities of the endogenous ligands (Table 4).

Of the 11 compound combinations ( $r=2$ and $r=3), 6$ combinations of RFV3 compounds showed higher binding affinity than the single compounds. Interaction analyses for all 6 best docked models were performed and results shown in Table 4. The common maximum number of binding interactions for individual test compounds or their combinations with all three CLAs and the GW590735 agonist, was 8. This number of interactions was only produced by the individual compound trans-pterostilbene, the combination (trans-pterostilbene, xymenynic acid and glyceryl linolenate) and the RFV3 combination. When examining three constituents of RFV3 (Glyceryl Linoleate, Xymenynic Acid and Glyceryl
Linolenate) at $r=2$ and $r=3$ combinations we found commonality with the binding residues of cis-9, cis-12 as highlighted yellow in Table 4. Shown in Figure 3A, a conformation of (ximenynic acid + glyceryl linolenate) demonstrates ligands organized in one arm of the binding cavity. Figure $3 \mathrm{~B}$ and $\mathrm{C}$ demonstrates ligands filling more than one arm of the PPAR Y-shaped cavity with trans-pterostilbene binding in an alternate arm/or sub-pocket of the cavity as compared to the other RFV3 complex constituents. In addition, RFV3 exhibits a superior binding affinity than the endogenous ligand and equivalent or better binding affinity than the individual test compounds indicating a good possibility for cooperative ligand binding.

\section{Ex-vivo Explants}

Effect of Treatments on Tissue and Cell Morphology Microscopic observations showed no alterations occurring in the dermis and epidermis across all samples. All samples appeared consistent with the untreated (control) day 0 


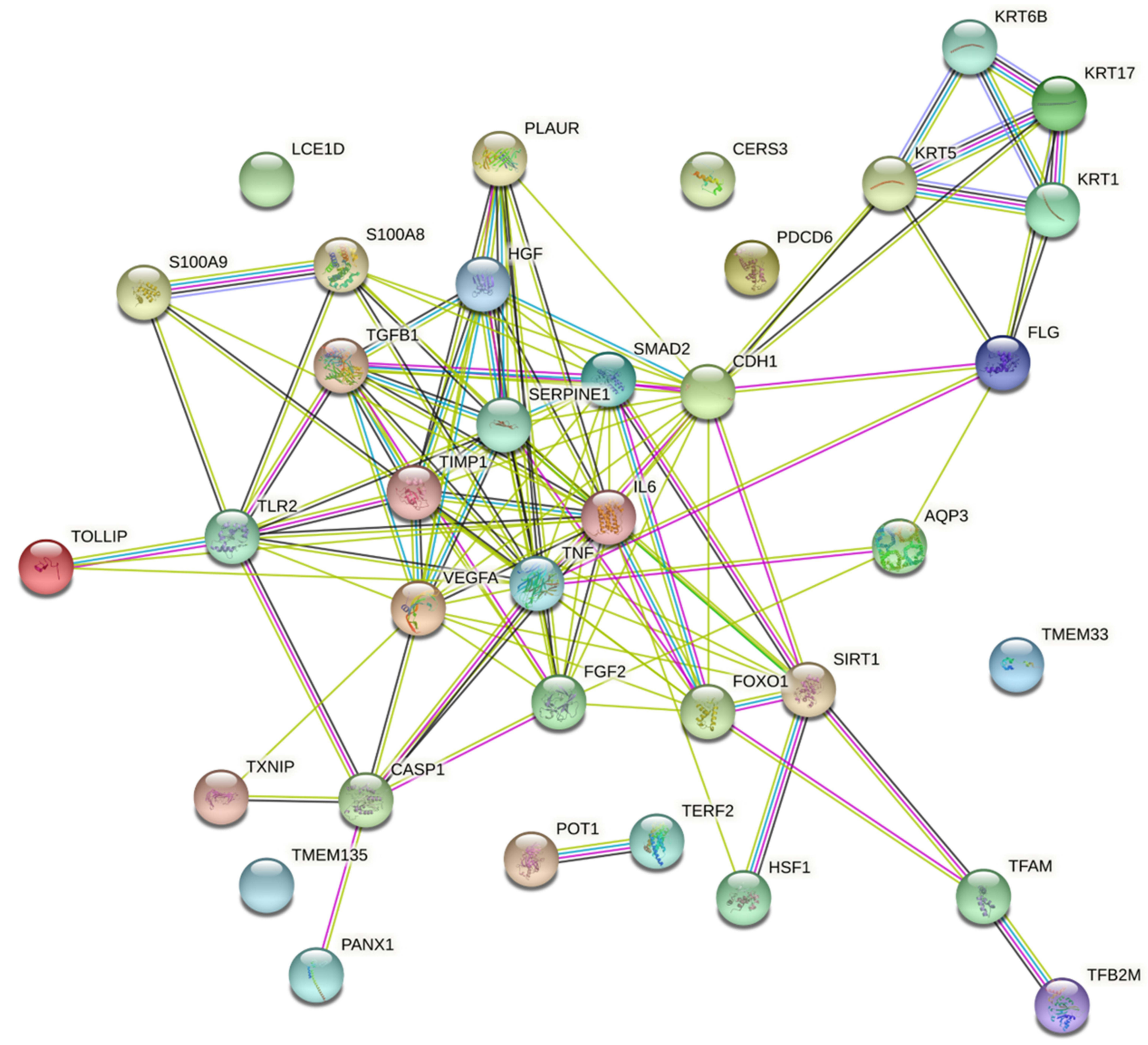

Figure 2 Graphic representation of connectivity in genes modulated by RFV3 (2\%) in epidermal tissue substitutes vs glycerin control (in silico analysis with StringDB software).

explant and all explants were graded as "G". Treatment with RFV3 (at $0.5 \%, 3 \%, 5 \% \mathrm{w} / \mathrm{w}$ dilutions) did not induce any alterations to the explants as shown in Figure 4.

\section{Effect of Treatments on Ceramide Content in Delipidated Explants}

After 3 hours, RFV3-treated samples resulted in slight and moderate increases of ceramide content (with $0.5 \%, 3 \%$, $5 \%$ ) with respect to the excipient treated control. After 24 hours, RFV3-treated samples resulted in a significant increase $(\mathrm{p}<0.01)$ in ceramide content with respect to the excipient treated samples $(182 \%$ with $0.5 \%$ RFV3,
$339 \%$ with 3\% RFV3, and 393\% with 5\% RFV3). A significant $(\mathrm{p}<0.01)$ increase was also observed in comparison to the delipidated control $(161 \%$ with $0.5 \%$ RFV3, 307\% with 3\% RFV3 and 357\% with 5\% RFV3), represented in Figures 5 and 6.

\section{Effect of Treatments on Filaggrin Content in Delipidated Explants}

After 3 hours, RFV3-treated samples resulted in a slight increase in filaggrin content (with 3\% RFV3 and 5\% RFV3). After 24 hours, RFV3-treated samples resulted in a significant increase $(\mathrm{p}<0.01)$ in filaggrin content with respect to the excipient treated samples $(30 \%$ increase with 
Table 4 Binding Affinity and Amino Acid Interacting Residues of GW590735, Endogenous Ligands (CLAs), Test Compounds and Complexes of Compounds. Bolded Amino Acid Interacting Residues Represent Common Binding Sites of GW590735, a Known Synthetic PPAR- $\alpha$ Agonist

\begin{tabular}{|c|c|c|c|c|}
\hline $\begin{array}{l}\text { CID } \\
\text { Number }\end{array}$ & Compound Name & $\begin{array}{l}\text { Binding } \\
\text { Affinity } \\
\text { (-Kcal } \\
\text { /mol) }\end{array}$ & $\begin{array}{l}\text { Amino Acid Interacting Residues Common } \\
\text { Residues with:GW590735 = bold } \\
\text { CLA, cis-9, trans- } 1 \text { I = blue } \\
\text { CLA, trans-10, cis- } 12 \text { = green } \\
\text { CLA, cis-9, cis- } 12 \text { = yellow }\end{array}$ & $\begin{array}{l}\text { Number of Common } \\
\text { Interacting Residues with } \\
\text { All CLAs and GW735469 }\end{array}$ \\
\hline 9956726 & GW590735 & -8 & $\begin{array}{c}\text { CYS-275, VAL-332, CYS-276, MET-355, SER- } \\
\text { 280, TYR-3 I4, HIS-440, TYR-464 }\end{array}$ & - \\
\hline 5280644 & CLA, cis-9, trans-II & -6.1 & $\begin{array}{l}\text { LYS-358, MET-355, GLU-356, GLU-439, HIS-440, } \\
\text { ALA-44I, LEU-443, ASP-353, ILE-354 }\end{array}$ & - \\
\hline 5282800 & CLA, trans-10, cis- 12 & -6 & ARG-27I, ILE-272, CYS-275, CYS-276 & - \\
\hline 5280450 & CLA, cis-9, cis- 12 & -5.8 & $\begin{array}{c}\text { MET-220, ASN-2I9, ASN-22I, ASN-217, PHE-2I8, } \\
\text { GLU-286, MET-320 }\end{array}$ & - \\
\hline \multicolumn{5}{|c|}{ Binding affinity of combination of compounds when $n=4$ and $r=1$} \\
\hline 5283469 & Glyceryl linoleate & -6.7 & $\begin{array}{l}\text { MET-320, LYS-222, LEU-32I, SER-323, ILE-375, SER- } \\
\text { 376, LEU-377, PHE-378, VAL-379, THR-283, ALA- } \\
\text { 316, ILE-3 I7, TYR-2 I4, ALA-3 I9, SER-323, ASP-37I, } \\
\text { ASP-372, ASP-374 }\end{array}$ & 1 \\
\hline 5312688 & Xymenynic acid & -6.1 & $\begin{array}{l}\text { SER-280, TYR-3 I4, GLU-3I5, ALA-3I6, ILE-3I7, } \\
\text { PHE-3 I8, HIS-440, TYR-464, GLY-3I2, VAL-3I3 }\end{array}$ & 5 \\
\hline 5367328 & Glyceryl linolenate & -6.6 & $\begin{array}{l}\text { CYS-275, THR-279, ALA-333, CYS-276, CYS-278, } \\
\text { THR-279, VAL-332, TYR-334, ILE-272, HIS-274 }\end{array}$ & 6 \\
\hline 5281727 & Trans-pterostilbene & -6.7 & $\begin{array}{c}\text { CYS-276, THR-279, SER-280, THR-283, ALA-333, } \\
\text { LYS-358, HIS-440, CYS-275 }\end{array}$ & 8 \\
\hline \multicolumn{5}{|c|}{ Binding affinity of combination of compounds when $n=4$ and $r=2$} \\
\hline $\begin{array}{l}5283469 \text { and } \\
5312688\end{array}$ & $\begin{array}{l}\text { Glyceryl Linoleate and } \\
\text { Xymenynic Acid }\end{array}$ & -7.5 & $\begin{array}{l}\text { MET-220, ASN-22 I, LYS-222, VAL-223, SER-323, } \\
\text { VAL-324, TYR-214, ASP-372 }\end{array}$ & 2 \\
\hline $\begin{array}{l}5283469 \text { and } \\
5367328\end{array}$ & $\begin{array}{l}\text { Glyceryl Linoleate and } \\
\text { Glyceryl Linolenate }\end{array}$ & -7.8 & $\begin{array}{l}\text { ASN-219, MET-220, GLU-282, THR-283, VAL-284, } \\
\text { SLU-286, TYR-334, THR-279, THR-283, CYS-278, } \\
\text { SER-280, VAL-28I }\end{array}$ & 4 \\
\hline $\begin{array}{l}5283469 \text { and } \\
5281727\end{array}$ & $\begin{array}{l}\text { Glyceryl Linoleate and } \\
\text { Trans-pterostilbene }\end{array}$ & -6.6 & Not evaluated & \\
\hline $\begin{array}{l}5312688 \text { and } \\
5367328\end{array}$ & $\begin{array}{l}\text { Xymenynic Acid and } \\
\text { Glyceryl Linolenate }\end{array}$ & -7 & $\begin{array}{c}\text { TYR-3 I 4, GLU-3 I5, ALA-3 I6, ILE-3 I7, ALA-3I9, } \\
\text { MET-320, LEU-32 I, LYS-358, VAL-437, HIS-440, } \\
\text { TYR-464, VAL-3I3, LEU-433, LEU-436 }\end{array}$ & 3 \\
\hline $\begin{array}{l}5312688 \text { and } \\
5281727\end{array}$ & $\begin{array}{l}\text { Xymenynic Acid and Trans- } \\
\text { pterostilbene }\end{array}$ & -6.3 & Not evaluated & \\
\hline $\begin{array}{l}5367328 \text { and } \\
5281727\end{array}$ & $\begin{array}{l}\text { Glyceryl Linolenate and } \\
\text { Trans-pterostilbene }\end{array}$ & -6.6 & Not evaluated & \\
\hline
\end{tabular}


Table 4 (Continued).

\begin{tabular}{|c|c|c|c|c|}
\hline $\begin{array}{l}\text { CID } \\
\text { Number }\end{array}$ & Compound Name & $\begin{array}{l}\text { Binding } \\
\text { Affinity } \\
\text { (-Kcal } \\
\text { Imol) }\end{array}$ & $\begin{array}{l}\text { Amino Acid Interacting Residues Common } \\
\text { Residues with:GW590735 = bold } \\
\text { CLA, cis-9, trans- } 11=\text { blue } \\
\text { CLA, trans- } 10 \text {, cis- } 12=\text { green } \\
\text { CLA, cis-9, cis- } 12=\text { yellow }\end{array}$ & $\begin{array}{l}\text { Number of Common } \\
\text { Interacting Residues with } \\
\text { All CLAs and GW735469 }\end{array}$ \\
\hline \multicolumn{5}{|c|}{ Binding affinity of combination of compounds when $n=4$ and $r=3$} \\
\hline $\begin{array}{l}5281727 \\
5283469 \text { and } \\
5312688\end{array}$ & $\begin{array}{l}\text { Trans-pterostilbene, } \\
\text { Glyceryl Linoleate and } \\
\text { Xymenynic Acid }\end{array}$ & -6.3 & Not evaluated & \\
\hline $\begin{array}{l}5281727, \\
5283469 \text { and } \\
5367328\end{array}$ & $\begin{array}{l}\text { Trans-pterostilbene, } \\
\text { Glyceryl Linoleate and } \\
\text { Glyceryl Linolenate }\end{array}$ & -6.5 & Not evaluated & \\
\hline $\begin{array}{l}5281727 \\
5312688 \text { and } \\
5367328\end{array}$ & $\begin{array}{l}\text { Trans-pterostilbene, } \\
\text { Xymenynic Acid and } \\
\text { Glyceryl Linolenate }\end{array}$ & -7.2 & $\begin{array}{c}\text { CYS-275, CYS-276, THR-279, SER-280, THR- } \\
\text { 283, HIS-440, ALA-333, LYS-358 }\end{array}$ & 8 \\
\hline $\begin{array}{l}5283469 \\
5312688 \text { and } \\
5367328\end{array}$ & $\begin{array}{l}\text { Glyceryl Linoleate, } \\
\text { Xymenynic Acid and } \\
\text { Glyceryl Linolenate }\end{array}$ & -7.5 & $\begin{array}{l}\text { M24, TYR-2I4, MET-220, ALA-319, VAL-3I3, ALA- } \\
316\end{array}$ & 2 \\
\hline \multicolumn{5}{|c|}{ Binding affinity of combination of compounds when $n=4$ and $r=4$} \\
\hline $\begin{array}{l}5281727 \\
5283469 \\
5367328 \text { and } \\
5312688\end{array}$ & $\begin{array}{l}\text { Trans-pterostilbene, } \\
\text { Glyceryl Linoleate, Glyceryl } \\
\text { Linolenate and Xymenynic } \\
\text { Acid } \\
\text { (RFV3 Complex) }\end{array}$ & -7.4 & $\begin{array}{c}\text { CYS-275, CYS-276, THR-279, SER-280, THR- } \\
\text { 283, HIS-440, ILE-272 }\end{array}$ & 8 \\
\hline
\end{tabular}

3\% RFV3, and 71\% increase with 5\% RFV3). When comparing against the delipidated control the filaggrin increase was significant $(p<0.01)$ with $(41 \%$ increase with 3\% RFV3, and $85 \%$ increase with 5\% RFV3). At a dilution of $0.5 \%$ RFV3 did not produce a significant result, represented in Figures 7 and 8.
Effect of Treatments on Transglutaminase-I Content in Delipidated Explants

After 3 hours, RFV3-treated samples resulted in slight decreases in TGM1 content (with $0.5 \%$ RFV3 and 3\% RFV3) and slight increase (with 5\% RFV3). After 24 hours of treatment, the excipient-treated samples produced
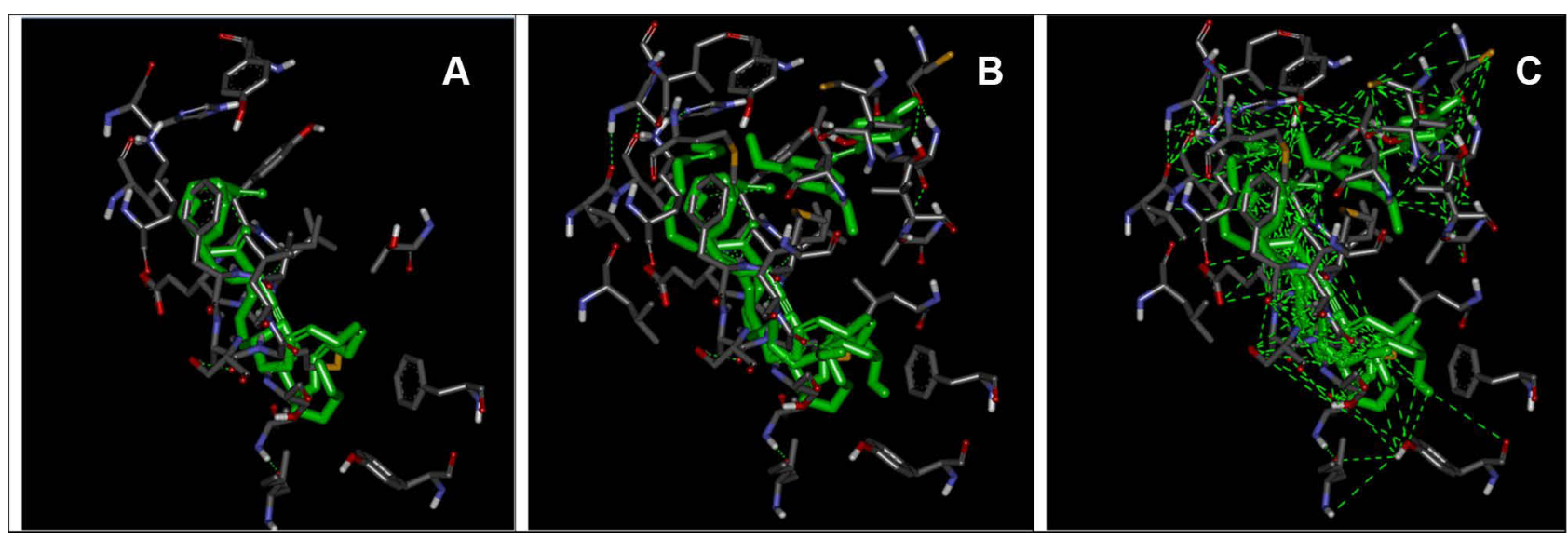

Figure 3 Interacting amino acid residues and conformations within the LBD of PPAR- $\alpha$. From left to right: (A) ximenynic acid + glyceryl linolenate at distance criterion of $2.5 \dot{A},(B)$ RFV3 at distance criterion of $2.5 \dot{A}$ and (C) RFV3 at distance criterion of $6 \dot{\mathrm{A}}$. 


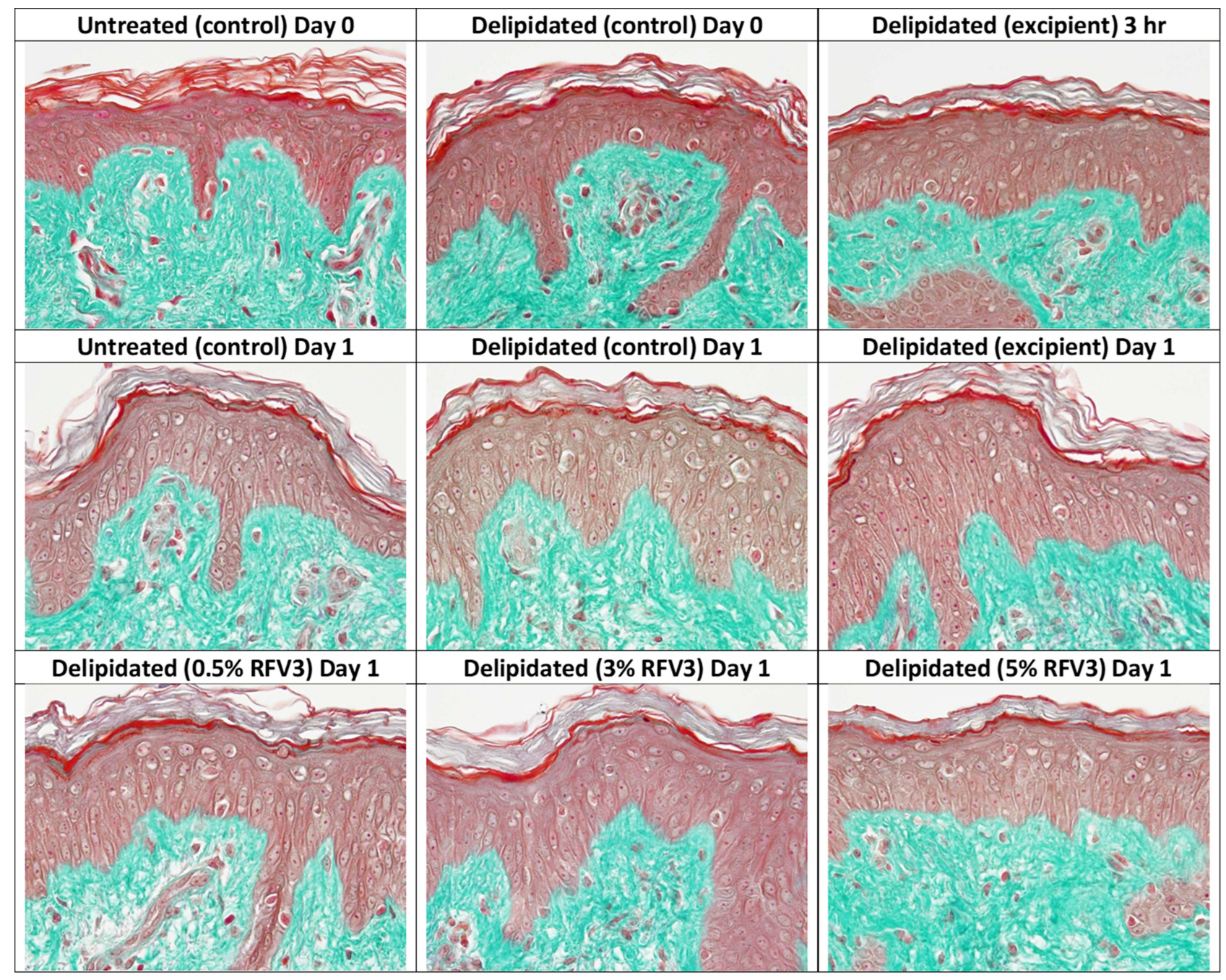

Figure 4 Microscopic evaluation of tissue and cell morphology of day 0 and day I explants. No alterations observed in the epidermis and dermis across all samples.

a significant $(\mathrm{p}<0.01)$ decrease in TGM1 by $-39 \%$ with respect to the delipidated control. After 24 hours, RFV3treated samples resulted in a significant increase $(\mathrm{p}<0.01)$ in TGM1 content with respect to the excipient treated samples (124\% with $0.5 \%$ RFV3, $156 \%$ with $3 \%$ RFV3 and $173 \%$ with $5 \%$ RFV3). A significant $(\mathrm{p}<0.01)$ increase was also observed in comparison to the delipidated control $(57 \%$ with $3 \%$ RFV3 and $68 \%$ with $5 \%$ RFV3), represented in Figures 9 and 10.

\section{Discussion}

Skincare products have in the past utilized plant-derived oils such as CLAs in their formulations for conditioning skin and the maintenance of skin barrier function. However, CLAs pose some challenges including standardized quality sources and managing the oxidative stability of formulated CLAs. This often leads to formation of rancid odor upon oxidation. If applied to skin, peroxidized CLAs may promote oxidation of other unsaturated skin lipids. Peroxidation of unsaturated fatty acids in skin is known to produce a variety of compounds some of which are reactive, mutagenic (eg, malondialdehyde) or toxic (eg, 4-hydroxynonenal). ${ }^{66}$ Testing for malondialdehyde in skin models after exposures to various oxidative stressors has become a growing area of study. Recent PPAR activators including hydroxystearic acid and octadecenedioic acid have shown very promising applications in managing age spots, pigmentation, supporting collagen-boosting and barrier function, and addressing other visible age-related changes in skin. ${ }^{47,67,68}$ While some formulation limitations still exist, they herald the value of PPAR activators in skin care products, as they become better recognized by industry formulators and product developers. 


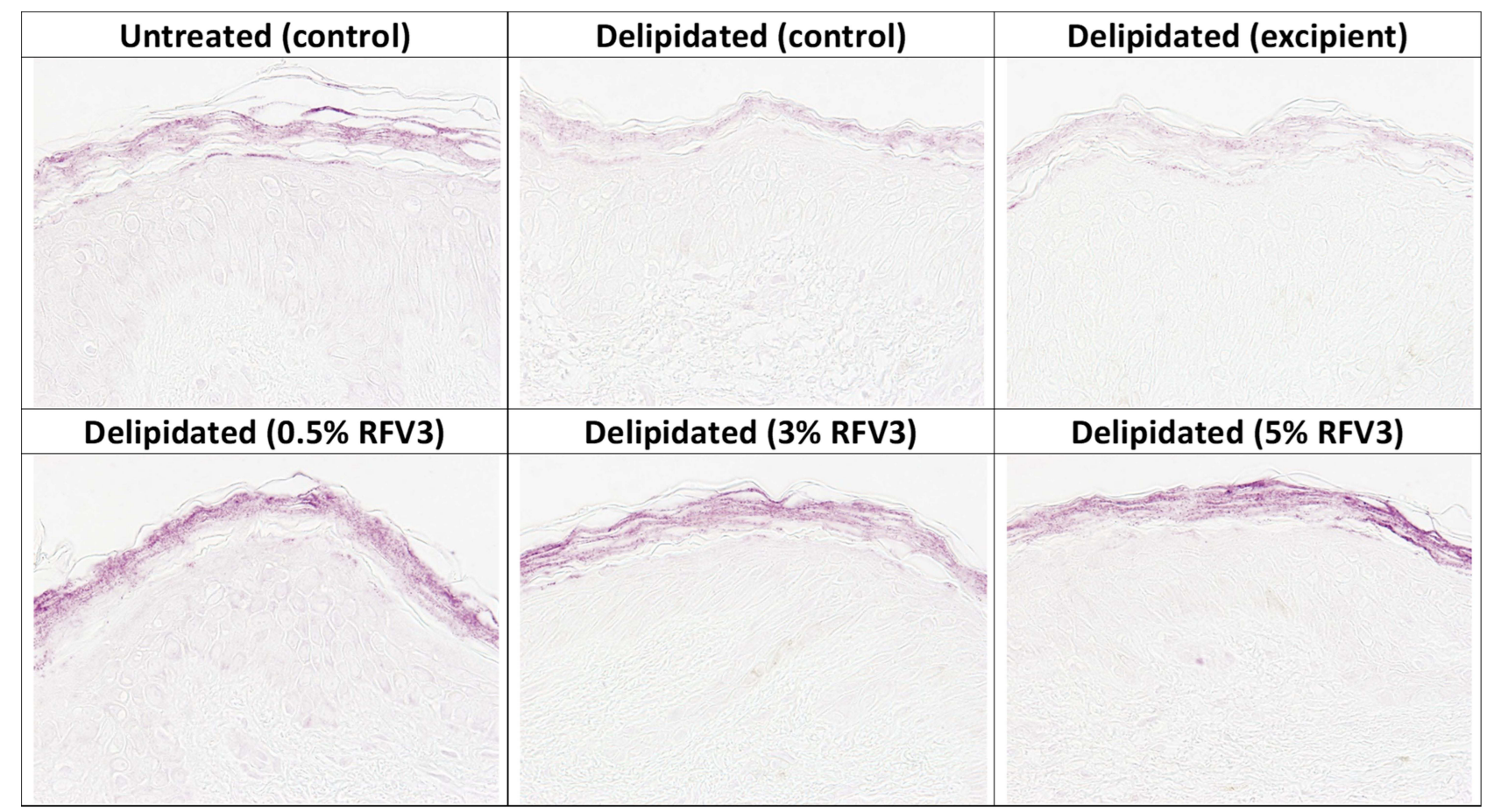

Figure 5 Immunostaining of ceramides in the stratum corneum with day I explants. Starting top left samples: Untreated control, delipidated control, delipidated excipient treated, delipidated $0.5 \%$ RFV3 treated, delipidated $0.3 \%$ RFV3 treated, delipidated $5 \%$ RFV 3 treated.

\section{Ceramides (\% surface) in the stratum corneum}

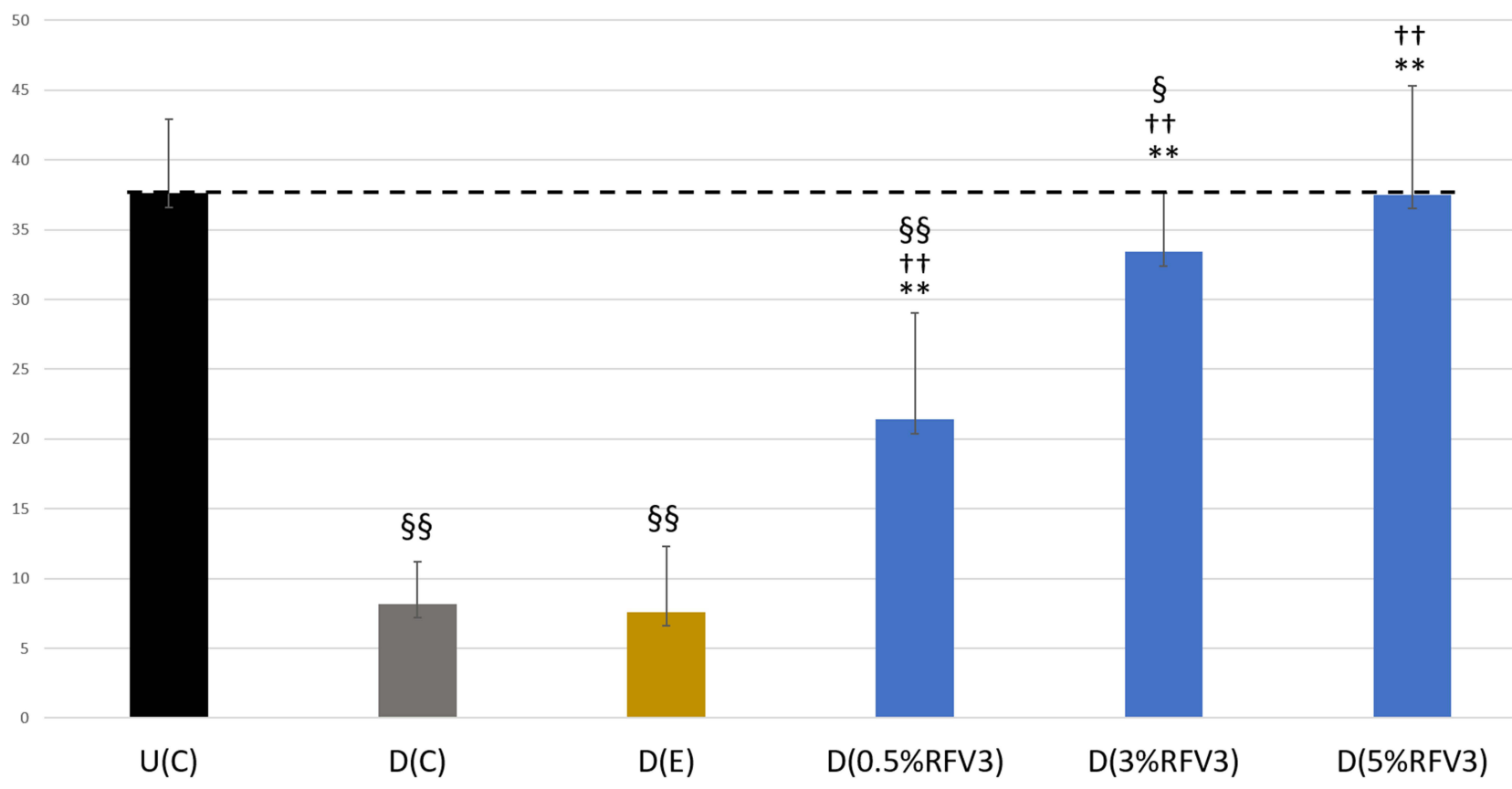

Figure 6 Image analysis for \% surface positive immunostaining of ceramides in the stratum corneum of day I explants. Error bars represent SD. Explants analyzed: 18 (6 batches, 3 explants per batch). Image analyses $n=9$ ( 3 images per explant). Treated samples vs $U(C)$ : $\S$ for $p<0.05$ and $\S \S$ for $p<0.01$. Treated vs $D(C)$ : $\dagger \dagger$ for $p<0.01$. Treated samples vs $\mathrm{D}(\mathrm{E}) * *$ for $\mathrm{p}<0.01$. 


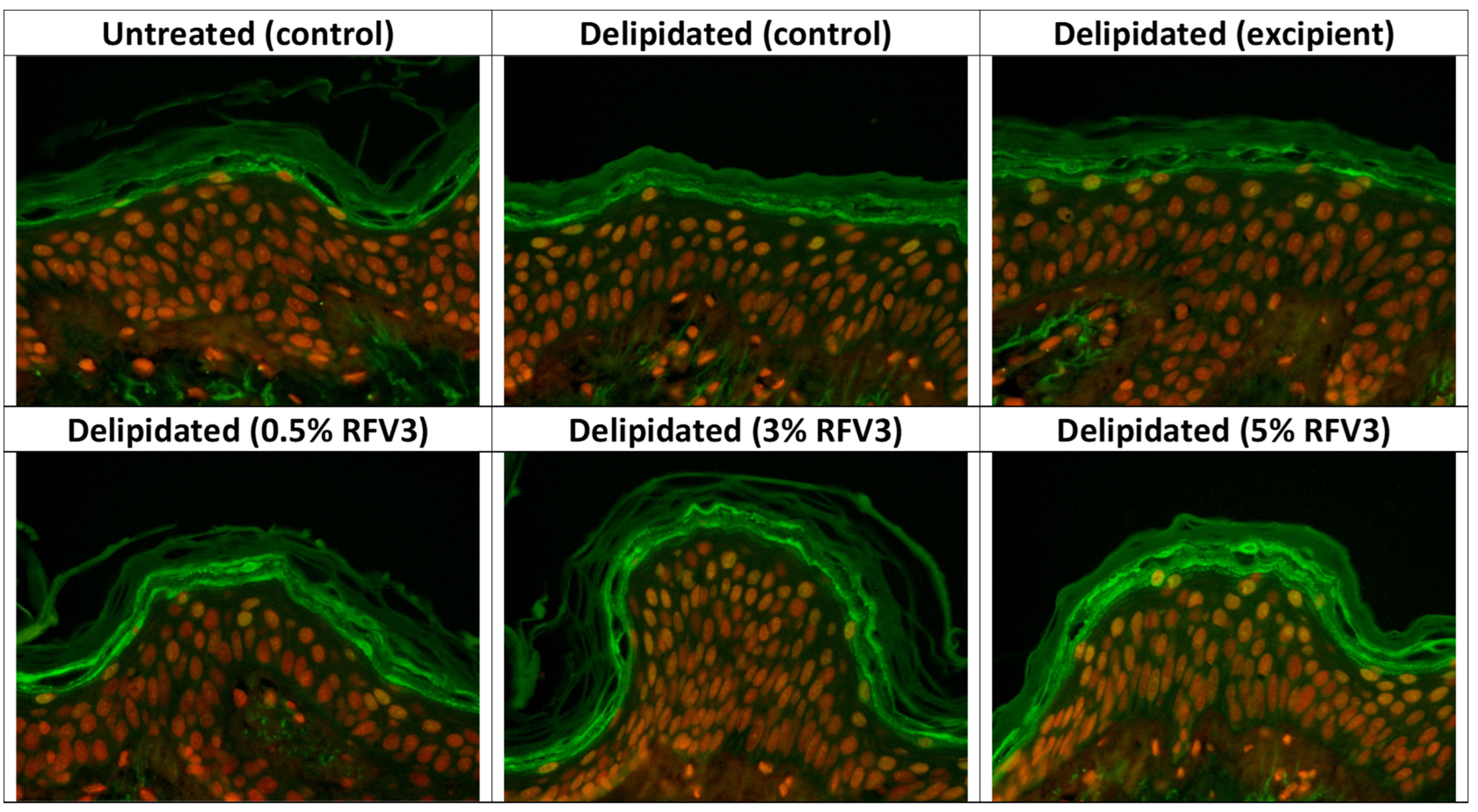

Figure 7 Immunostaining of filaggrin at the bottom of the stratum corneum with day I explants. Starting top left samples: Untreated control, delipidated control, delipidated excipient treated, delipidated $0.5 \%$ RFV3 treated, delipidated $0.3 \%$ RFV3 treated, delipidated $5 \%$ RFV 3 treated.

\section{Filaggrin (\% surface) in bottom stratum corneum}

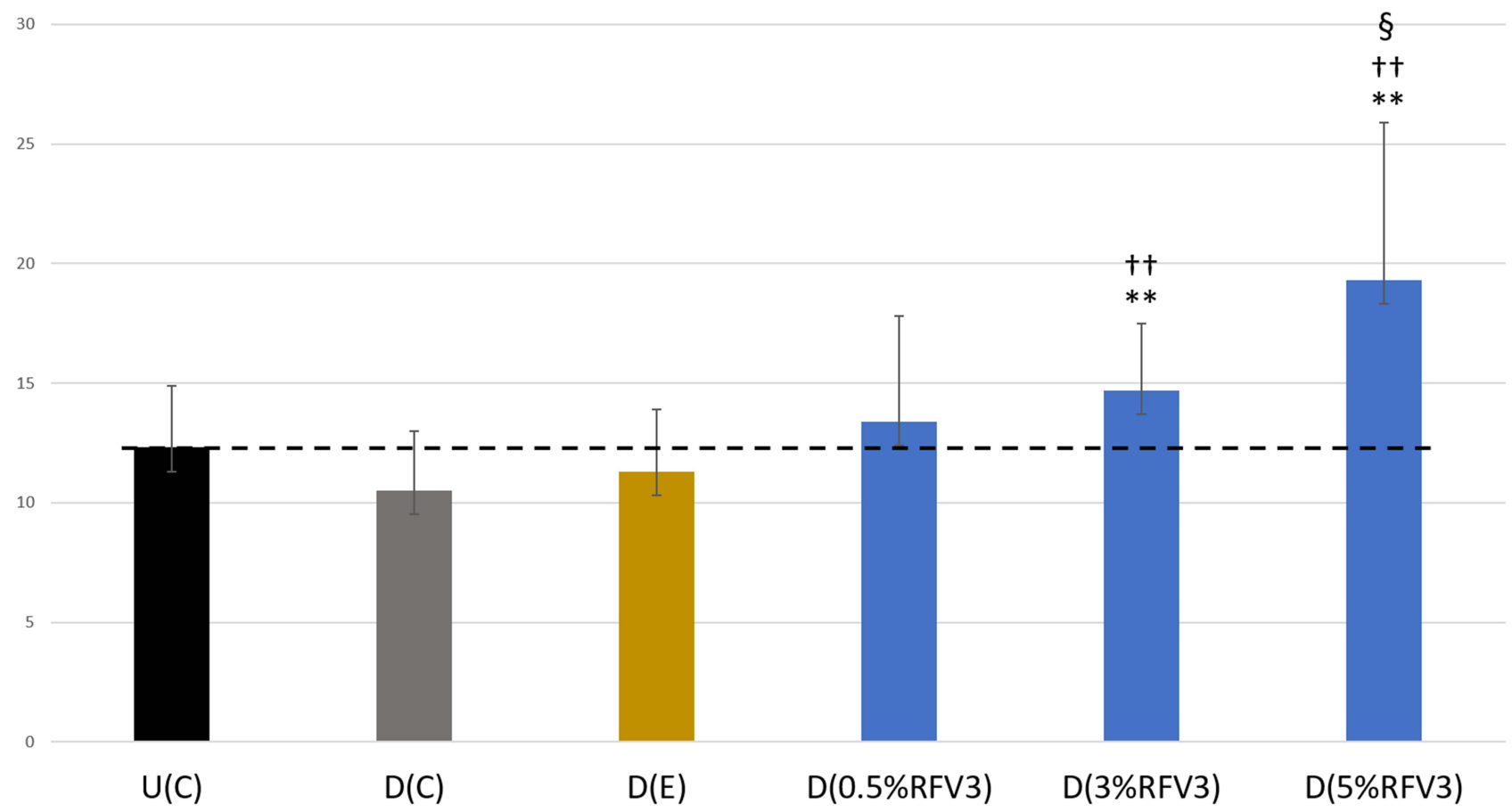

Figure 8 Image analysis for \% surface positive immunostaining of filaggrin at the bottom of the stratum corneum with day I explants. Error bars represent SD. Explants analyzed: 18 (6 batches, 3 explants per batch). Image analyses $n=9$ ( 3 images per explant). Treated samples vs $U(C)$ : $\S$ for $p<0.05$. Treated vs $D(C)$ : $\dagger \dagger$ for $p<0.0$ I. Treated samples vs $D(E) * *$ for $p<0.01$. 


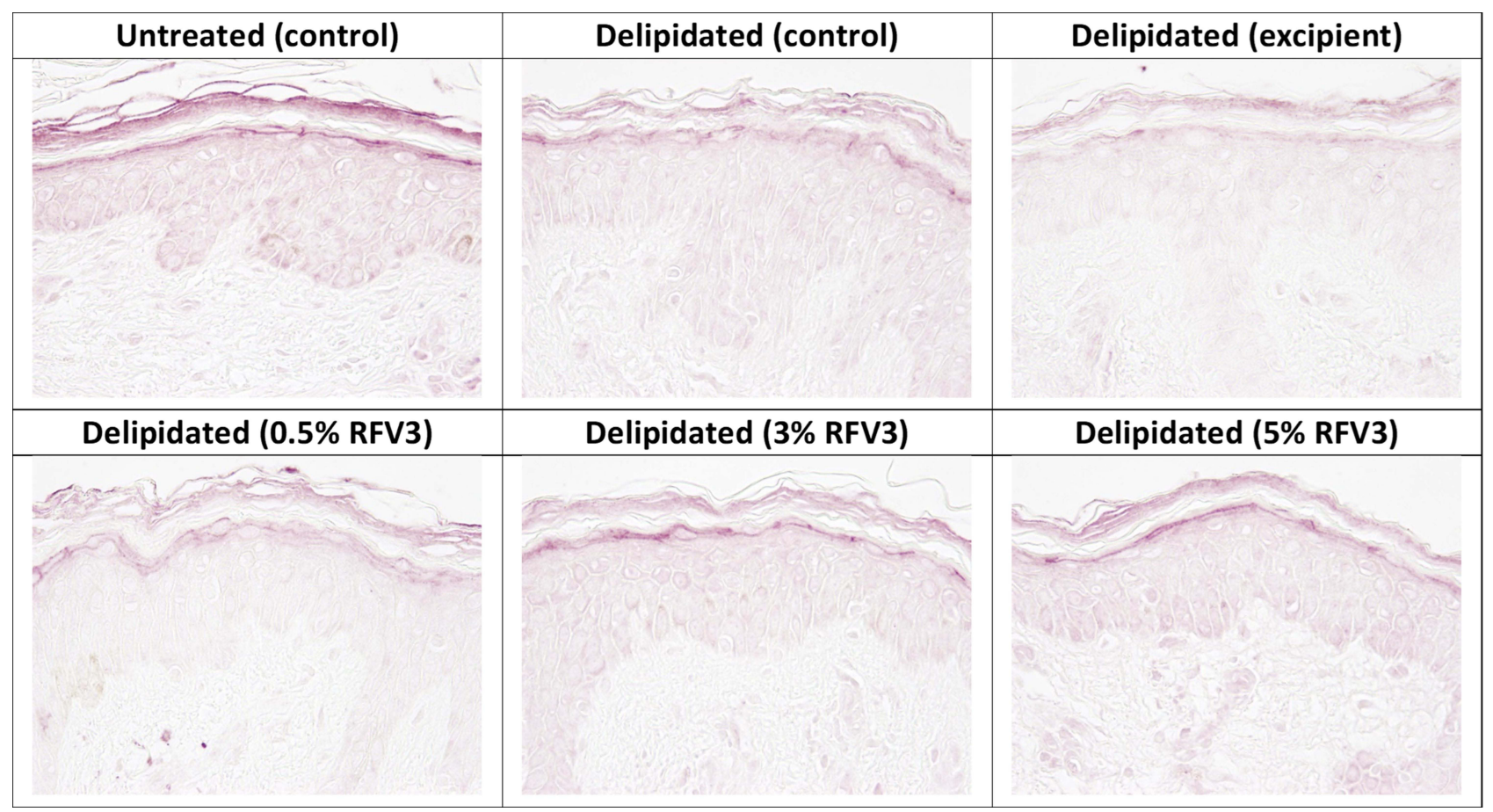

Figure 9 Immunostaining of transglutaminase-I in the epidermis granular layer with day I explants. Starting top left samples: Untreated control, delipidated control, delipidated excipient treated, delipidated $0.5 \%$ RFV3 treated, delipidated $0.3 \%$ RFV3 treated, delipidated $5 \%$ RFV3 treated.

\section{TGM1 (\% surface) in the granular layer of the epidermis}

60

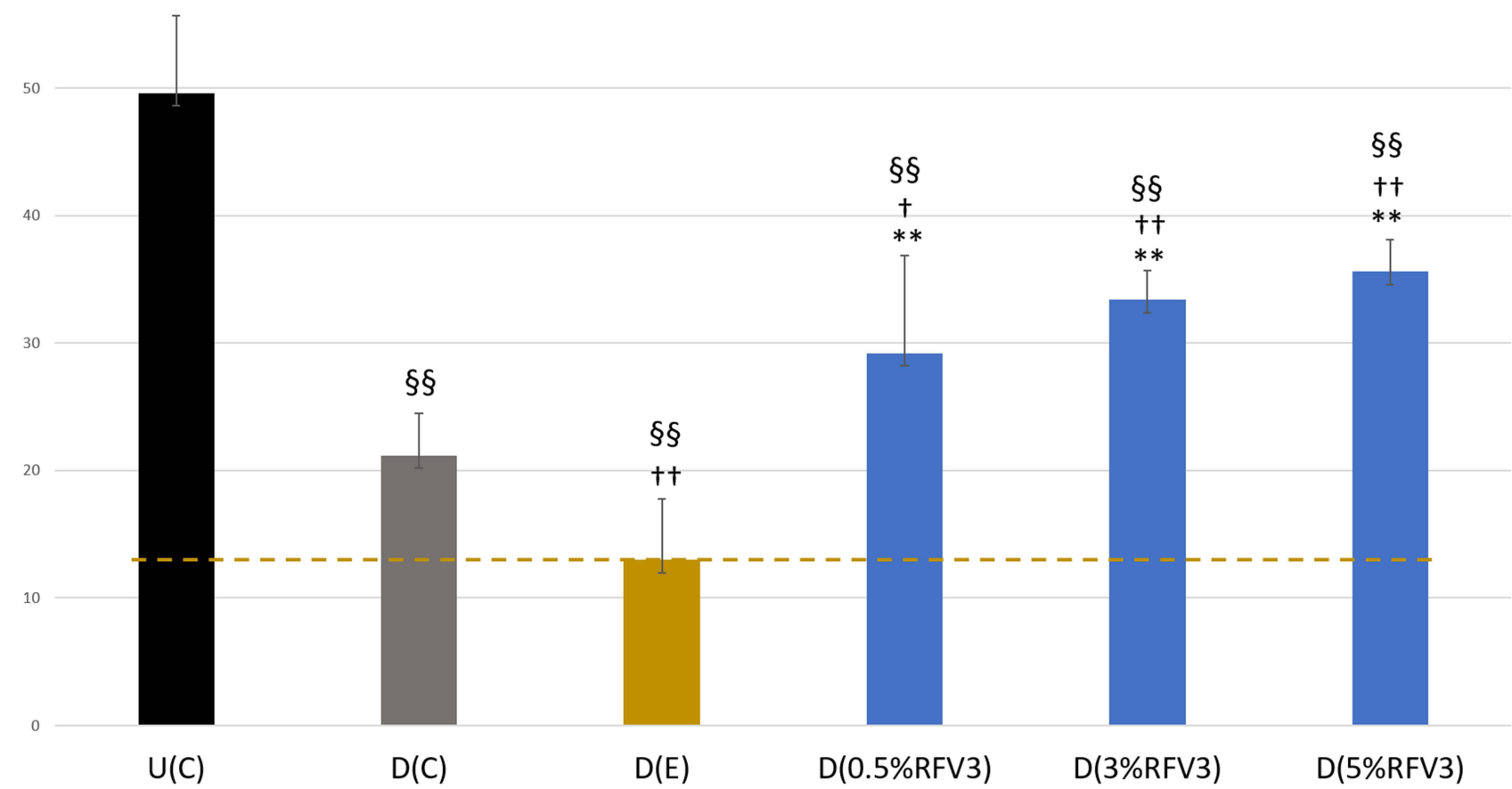

Figure 10 Image analysis for \% surface positive immunostaining of transglutaminase-I in the epidermis granular layer with day I explants. Error bars represent SD. Explants analyzed: 18 (6 batches, 3 explants per batch). Image analyses $n=9$ ( 3 images per explant). Treated samples vs $U(C): \S \S$ for $p<0.01$. Treated vs $D(C)$ : $\dagger$ for $p<0.05$ and $\nmid \dagger$ for $\mathrm{p}<0.01$. Treated samples vs $\mathrm{D}(\mathrm{E}) * *$ for $\mathrm{p}<0.01$. 
Our RFV3 complex has several key features distinguishing it from other PPAR- $\alpha$ agonists used in skincare applications. Its composition is a mixture of glycerol esters of CLAs, a plant-derived stilbene and an acetylenic fatty acid. The glycerol CLA esters act as topical penetration enhancers, solubilizers, and offer a source of both CLAs and glycerol (natural moisturizing factor) upon hydrolysis in skin with exposure to human esterases. The antioxidant properties of trans-pterostilbene are valuable for inhibiting oxidation of the unsaturated fatty acid chains. While some of these compounds are capable of slight to moderate PPAR- $\alpha$ agonism, when combined they are able to interact in a cooperative manner to produce significant PPAR- $\alpha$ activation as demonstrated by our in vitro data.

It is worth noting that challenges exist when comparing PPAR agonists on a molar scale especially when measuring mixtures of plant-derived agonists or comparing agonists with different dose responses and cytotoxic concentrations. In our study, the highly efficient synthetic positive control GW590735 was tested at the recommended maximum dose response concentration of 0.143 $\mu \mathrm{g} / \mathrm{mL}$ and produced a strong $341 \%$ transcriptional increase with respect to the water control to confirm integrity of our experiment. RFV3 at much less efficient concentrations $(250 \mu \mathrm{g} / \mathrm{mL}$ and $500 \mu \mathrm{g} / \mathrm{mL})$ yielded superior transcriptional outputs between 491-968\% demonstrating both the low cytotoxic characteristics of RFV3 and its ability to effectively induce a transcriptional response. In consumer product formulation, the efficacy (activity/mol) is of lesser consideration as ingredients are often formulated at higher dosing to compensate for the dynamics of topical delivery. Ultimately product efficacy is determined using ex vivo and in vivo techniques with a different set of endpoints.

Our in silico findings further validated in vitro analyses and demonstrated that the RFV3 complex shares 8 common acid residues with a known synthetic PPAR- $\alpha$ agonist and endogenous ligands (CLAs). Interestingly, the in silico work also revealed the 3 isomeric linoleic ligands each displayed unique binding patterns with the amino acid residues which may indicate the ligands can act via different mechanisms. We speculate PPAR activation may respond to multiple ligands interacting individually or simultaneously at the binding site or through some other interaction, allosteric or otherwise, to influence activation.

Comparing against our CLA isomer reference standards (trans-10, cis-12), (trans-11, cis-9), (cis-9, cis-12) RFV3 demonstrated superior binding affinity against all three. It is likely that amino acid residues are also involved in maintaining the ligand conformations in the binding pocket as demonstrated by a significant number of hydrogen bonds $(>72)$ and direct amino acid interactions at a distance criterion of $6 \dot{A}$ (Figure 3C). RFV3 also differed from trans-pterostilbene by binding at ILE-272, a common binding residue of CLA, trans-10, cis-12. Consistent with our hypothesis, RFV3 demonstrated its own unique binding pattern and a possibility for co-binding, by accessing multiple sub-pockets of the Y-shaped LBD while occurring at more stable binding affinities than the individual components or the endogenous ligands.

Although our PCR screening was limited to a 96 array gene plate and run without a positive control, our gene expression findings support a pattern consistent with PPAR activation. Epidermal substitutes treated with RFV3 complex differentially expressed genes involved in inflammation, epidermal homeostasis and epidermal barrier function. Of these results we found a down regulation of the inflammatory genes TNF- $\alpha$ and IL- 6 by -13.7 fold and -2.5 fold, respectively.

During SC formation, the sequential differentiation of keratinocytes is tightly regulated by genes in the Epidermal Differentiation Complex (EDC). ${ }^{69}$ The EDC contains three clustered families of genes: (1) cornified envelope precursor family, (2) calcium-binding proteins (S100A) protein family, and (3) the S100 fused type proteins. These genes are involved in the formation of the SC and specific members are expressed at distinct times during keratinocyte differentiation. The initiation of the SC is accompanied with a concomitant decrease in expressions of KRT1 and KRT10, and an increase in KRT14 and KRT5. ${ }^{29}$ This is followed by the expression of cornified envelope precursors involucrin (IVL) and transglutaminase (TGM1). Late differentiation markers including the cornified envelope protein loricrin (LOR) and the precursor of the keratin cross-linking protein filaggrin (FLG) are expressed in keratinocytes. ${ }^{30}$ Furthermore, differentiated keratinocytes exhibit increased expression of ceramide synthase CERS3 involved in the synthesis of acylceramides that serve as precursors to protein-bound ceramides critical in skin barrier function. ${ }^{70}$ Interestingly, despite the limited number of genes tested by our PCR analysis, we were able to identify down regulation of KRT1 and S100A9, upregulation of KRT5, CERS3, FLG, demonstrating relevance with the formation of the permeability barrier. These modulated genes play major roles in epithelial barrier dysfunction and have been implicated in the 
pathogenesis of atopic dermatitis (AD). AD skin is marked by defects in terminal differentiation of keratinocytes, deficiencies in filaggrin and ceramides. SA100A9 proteins are upregulated in $\mathrm{AD}$ and keratinocytes activated by these proteins increase inflammatory IL-33 production. $^{71}$ A recent review suggests that the permeability barrier also undergoes aging-associated alterations which involve significant declines in both barrier lipids and proteins including filaggrin and loricrin. ${ }^{72}$

Given that ceramides and other lipids are an essential part of the intercellular lamellae which forms the epidermal barrier structure, it is common practice to delipidate explants prior to other treatments thereby compromising the barrier function for study. Delipidation of explants has also been shown to degrade the barrier protein filaggrin which is known to facilitate terminal differentiation contributing to epidermal formation. ${ }^{73}$ Typically, studies examining accelerated barrier repair are performed with shortened sampling periods of up to only one day. The reason being that delipidated explants tend to recover barrier structured quickly, within a few days of delipidation.

To confirm that RFV3 is capable of accelerated barrier repair, we selected a delipidated human explant model with 3 endpoints measuring changes in the contents of ceramides, filaggrin and transglutaminase-1. Delipidation successfully depleted ceramides from the stratum corneum. Less expectedly, delipidation also induced a decrease in transglutaminase-1 in the granular layer, validating the use of a delipidated model for this endpoint. On day 1, the delipidated control $\mathrm{D}(\mathrm{C})$ and the excipient-treated delipidated control $\mathrm{D}(\mathrm{E})$ did not demonstrate new ceramide synthesis. However, explants treated with RFV3 on day 1 , produced a significant dose-dependent increase in ceramides at all 3 dilutions with respect to $\mathrm{D}(\mathrm{C})$ and $\mathrm{D}(\mathrm{E})$. On day $1,3 \%$ RFV3 nearly recovered ceramide levels to the un-delipidated control U(C). While delipidation did not significantly degrade filaggrin in this study, RFV3 applied at $5 \%$ significantly increased filaggrin levels at day 1 above all three $U(C), D(C)$ and $D(E)$ controls demonstrating a potent stimulatory effect. Interestingly, on day 1 , the excipient was observed to exert a significant suppressive effect on transglutaminase-1 with respect to $\mathrm{U}(\mathrm{C})$ and $\mathrm{D}(\mathrm{C})$. However, the day 1 RFV3 at all 3 dilutions significantly increased TGM1 beyond the $\mathrm{D}(\mathrm{C})$ and $\mathrm{D}(\mathrm{E})$ controls but did not restore TGM1 to the $\mathrm{U}(\mathrm{C})$ levels. This may suggest that RFV3 produced both a protective effect against the excipient and stimulatory effect on TGM1. These histologic results combined with our PCR data suggest that RFV3 application was able to induce synthesis of these EB lipids and proteins. It is noteworthy that the 4 constituents of RFV3 are not known to induce synthesis of ceramides, filaggrin or transglutaminase-1 by themselves.

We speculate that this restoration of the epidermal barrier markers in delipidated explants, most likely occurs through PPAR-induced pathways relating to epidermal lipid and protein synthesis. These observations are consistent with studies by Takeda et al, where activation of PPAR- $\alpha$ increased ceramide synthesis and activity of glucocerebroside in the SC of human epidermal equivalents. ${ }^{49}$ This is an especially useful finding given that ceramide absorption into the skin after topical applications has many challenges. ${ }^{74}$ There is a paucity of evidence that convincingly demonstrates exogenously applied ceramides penetrate and augment lipids in the SC. Thus, inducing ceramide synthesis seems like a more promising approach than formulating ceramides for topical applications. ${ }^{74}$

To our knowledge, this is the first time a multimolecule complex composed of natural plant-derived extracts has been shown to act as a reversible PPAR- $\alpha$ agonist. RFV3 demonstrated a significant increase in PPAR- $\alpha$ transcription; and induced synthesis of ceramides, filaggrin and transglutaminase- 1 in a delipidated explant model. All three markers are known targets of PPAR- $\alpha$ implying that RFV3 successfully activated PPAR transcription to enhance the production of these markers. Furthermore, our reporter assay and in silico modeling data suggest that activation of PPAR- $\alpha$ by RFV3 occurred via an unconventional binding mechanism, reminiscent of cooperative binding where multiple ligands bind to more than one arm of the Y-shaped LBD. The implications of these results open the possibility of filling a larger portion of the PPAR cavity and/or subpockets, possibly achieving full or enhanced activation with more significant allosteric changes to PPAR. Further work is required to understand the complex nature of cooperative multi-ligand complexes and their in vivo applications to fully gauge RFV3's role on barrier function and skin care benefits.

\section{Acknowledgments}

The authors would like to thank Dr Smrita Singh for her work on molecular modeling. This study was funded by Rodan \& Fields. Medical writing and editorial support were provided by Pranali Pathare, $\mathrm{PhD}$ of $3 \mathrm{P}$ Scientific Communications, LLC and Stephanie Domier, MS of DomierScript, LLC and were funded by Rodan \& Fields. 


\section{Author Contributions}

All authors significantly contributed to the work reported, including conception, study design, execution, acquisition of data, analysis and interpretation, drafting, revising and critically reviewing the article; gave final approval of the version to be published; have agreed on the journal to which the article has been submitted; and agree to be accountable for all aspects of the work.

\section{Disclosure}

Authors JC and TF are employees of Rodan \& Fields, San Francisco, CA. Author GM was a consultant of Rodan \& Fields during the research presented within and development of this manuscript. Mr GM and Dr JC report being inventors on patent application PPAR AGONIST COMPLEX AND METHODS OF USE, PCT/US2020/ 064798; Dr Timothy Falla discloses a patent PCT/ US2020/064798 pending to Rodan + Fields. The authors report no other conflicts of interest in this work.

\section{References}

1. Chawla A. Nuclear receptors and lipid physiology: opening the X-files. Science (80-). 2001;294(5548):1866-1870. doi:10.1126/ science.294.5548.1866

2. Evans RM, Barish GD, Wang Y-X. PPARs and the complex journey to obesity. Nat Med. 2004;10(4):355-361.

3. Berger J, Moller DE. The mechanisms of action of PPARs. Annu Rev Med. 2002;53:409-435.

4. Cox RL. Rationally designed PPAR $\delta$-specific agonists and their therapeutic potential for metabolic syndrome. Proc Natl Acad Sci USA. 2017;114(13):3284-3285.

5. Schmuth M, Moosbrugger-Martinz V, Blunder S, Dubrac S. Role of PPAR, LXR, and PXR in epidermal homeostasis and inflammation. Biochim Biophys Acta. 2014;1841(3):463-473.

6. Angeli V, Hammad H, Staels B, Capron M, Lambrecht BN, Trottein F. Peroxisome proliferator-activated receptor gamma inhibits the migration of dendritic cells: consequences for the immune response. J Immunol. 2003;170(10):5295-5301.

7. Billoni N, Buan B, Gautier B, et al. Expression of peroxisome proliferator activated receptors (PPARs) in human hair follicles and PPAR alpha involvement in hair growth. Acta Derm Venereol. 2000;80(5):329-334.

8. Kang HY, Lee JY, Lee JS, Choi YM. Peroxisome proliferator-activated receptors-gamma activator, ciglitazone, inhibits human melanocyte growth through induction of apoptosis. Arch Dermatol Res. 2006;297(10):472-476.

9. Kim MJ, Deplewski D, Ciletti N, Michel S, Reichert U, Rosenfield RL. Limited cooperation between peroxisome proliferator-activated receptors and retinoid $\mathrm{X}$ receptor agonists in sebocyte growth and development. Mol Genet Metab. 2001;74 (3):362-369.

10. Lee JS, Choi YM, Kang HY. PPAR-gamma agonist, ciglitazone, increases pigmentation and migration of human melanocytes. Exp Dermatol. 2007;16(2):118-123. doi:10.1111/j.1600-0625.2006.005 21. $\mathrm{x}$
11. Michalik L, Wahli W. Peroxisome proliferator-activated receptors (PPARs) in skin health, repair and disease. Biochim Biophys Acta. 2007;1771(8):991-998. doi:10.1016/j.bbalip.2007.02.004

12. Rivier M, Safonova I, Lebrun P, Michel S, Griffiths CEM, Ailhaud G. Differential expression of peroxisome proliferator-activated receptor subtypes during the differentiation of human keratinocytes. J Invest Dermatol. 1998;111(6):1116-1121. doi:10.1046/j.1523-1747.1998.00439.x

13. Al Yacoub N, Romanowska M, Krauss S, Schweiger S, Foerster J. PPARdelta is a type 1 IFN target gene and inhibits apoptosis in T cells. J Invest Dermatol. 2008;128(8):1940-1949.

14. Braissant O, Foufelle F, Scotto C, Dauça M, Wahli W. Differential expression of peroxisome proliferator-activated receptors (PPARs): tissue distribution of PPAR-alpha, -beta, and -gamma in the adult rat. Endocrinology. 1996;137(1):354-366.

15. Braissant O, Wahli W. Differential expression of peroxisome proliferator-activated receptor-alpha, -beta, and -gamma during rat embryonic development. Endocrinology. 1998;139(6):2748-2754.

16. Downie MMT, Sanders DA, Maier LM, Stock DM, Kealey T. Peroxisome proliferator-activated receptor and farnesoid $\mathrm{X}$ receptor ligands differentially regulate sebaceous differentiation in human sebaceous gland organ cultures in vitro. Br J Dermatol. 2004;151 (4):766-775.

17. Dubrac S, Stoitzner P, Pirkebner D, et al. Peroxisome proliferator-activated receptor-alpha activation inhibits Langerhans cell function. J Immunol. 2007;178(7):4362-4372.

18. Dubrac S, Schmuth M. PPAR-alpha in cutaneous inflammation. Dermatoendocrinol. 2011;3(1):23-26.

19. Eastham LL, Mills CN, Niles RM. PPARalpha/gamma expression and activity in mouse and human melanocytes and melanoma cells. Pharm Res. 2008;25(6):1327-1333.

20. Faveeuw C, Fougeray S, Angeli V, et al. Peroxisome proliferator-activated receptor gamma activators inhibit interleukin-12 production in murine dendritic cells. FEBS Lett. 2000;486(3):261-266.

21. Greene ME, Pitts J, McCarville MA, et al. PPARgamma: observations in the hematopoietic system. Prostaglandins Other Lipid Mediat. 2000;62(1):45-73.

22. Hanley K, Jiang Y, Holleran WM, Elias PM, Williams ML, Feingold KR. Glucosylceramide metabolism is regulated during normal and hormonally stimulated epidermal barrier development in the rat. J Lipid Res. 1997;38(3):576-584.

23. Hanley K, Kömüves LG, Bass NM, et al. Fetal epidermal differentiation and barrier development In vivo is accelerated by nuclear hormone receptor activators. J Invest Dermatol. 1999;113(5):788-795.

24. Kömüves LG, Hanley K, Jiang Y, Elias PM, Williams ML, Feingold KR. Ligands and activators of nuclear hormone receptors regulate epidermal differentiation during fetal rat skin development. J Invest Dermatol. 1998;111(3):429-433.

25. Rivier M, Castiel I, Safonova I, Ailhaud G, Michel S. Peroxisome proliferator-activated receptor-alpha enhances lipid metabolism in a skin equivalent model. J Invest Dermatol. 2000;114(4):681-687.

26. Batheja P, Song Y, Wertz P, Michniak-Kohn B. Effects of growth conditions on the barrier properties of a human skin equivalent. Pharm Res. 2009;26(7):1689-1700.

27. Kömüves LG, Hanley K, Man MQ, Elias PM, Williams ML, Feingold KR. Keratinocyte differentiation in hyperproliferative epidermis: topical application of PPARalpha activators restores tissue homeostasis. J Invest Dermatol. 2000;115(3):361-367.

28. Del Rosso J, Zeichner J, Alexis A, et al. Understanding the epidermal barrier in healthy and compromised skin: clinically relevant information for the dermatology practitioner. $J$ Clin Aesthet Dermatol. 2016;9(4 suppl 1):S2-S8.

29. Kypriotou M, Huber M, Hohl D. The human epidermal differentiation complex: cornified envelope precursors, S100 proteins and the 'fused genes' family. Exp Dermatol. 2012;21:643-649. 
30. Goleva E, Berdyshev E, Leung D. Epithelial barrier repair and prevention of allergy. J Clin Invest. 2019;129(4):1463-1474.

31. Hanley K, Jiang Y, He S, et al. Keratinocyte differentiation is stimulated by activators of the nuclear hormone receptor PPAR $\alpha$. $J$ Invest Dermatol. 1998;110:368-375.

32. Kezic S, Jakasa I. Filaggrin and skin barrier function. Curr Probl Dermatol. 2016;49:1-7.

33. Elias PM, Choi EH. Interactions among stratum corneum defensive functions. Exp Dermatol. 2005;14:719-726.

34. Qingyang L, Fang H, Dang E, et al. The role of ceramides in skin homeostasis and inflammatory skin diseases. J Dermatol Sci. 2020;97(1):2-8.

35. Sertznig P, Reichrath J. Peroxisome proliferator-activated receptors (PPARs) in dermatology: challenge and promise. Dermatoendocrinol. 2011;3(3):130-135.

36. Fluhr JW, Man M-Q, Hachem J-P, et al. Topical peroxisome proliferator activated receptor activators accelerate postnatal stratum corneum acidification. J Invest Dermatol. 2009;129(2):365-374.

37. Behshad R, Cooper KD, Korman NJ. A retrospective case series review of the peroxisome proliferator-activated receptor ligand rosiglitazone in the treatment of atopic dermatitis. Arch Dermatol. 2008;144(1):84-88.

38. Boguniewicz M, Leung DYM. Atopic dermatitis: a disease of altered skin barrier and immune dysregulation. Immunol Rev. 2011;242(1):233-246.

39. Dahten A, Koch C, Ernst D, Schnöller C, Hartmann S, Systemic WM. PPARgamma ligation inhibits allergic immune response in the skin. $J$ Invest Dermatol. 2008;128(9):2211-2218.

40. Jung K, Tanaka A, Fujita H, et al. Peroxisome proliferator-activated receptor $\gamma$-mediated suppression of dendritic cell function prevents the onset of atopic dermatitis in NC/Tnd mice. J Allergy Clin Immunol. 2011;127(2):420-426.

41. Bongartz T, Coras B, Vogt T, Schölmerich J, Müller-Ladner U. Treatment of active psoriatic arthritis with the PPARgamma ligand pioglitazone: an open-label pilot study. Rheumatology. 2005;44 (1):126-129.

42. Mittal R, Malhotra S, Pandhi P, Kaur I, Dogra S. Efficacy and safety of combination Acitretin and Pioglitazone therapy in patients with moderate to severe chronic plaque-type psoriasis: a randomized, double-blind, placebo-controlled clinical trial. Arch Dermatol. 2009;145(4):387-393.

43. Robertshaw H, Friedmann PS. Pioglitazone: a promising therapy for psoriasis. Br J Dermatol. 2005;152(1):189-191.

44. Shafiq N, Malhotra S, Pandhi P, Gupta M, Kumar B, Sandhu K. Pilot trial: pioglitazone versus placebo in patients with plaque psoriasis (the P6). Int J Dermatol. 2005;44(4):328-333.

45. Liu Y, Meng Y, Li H, et al. Growth inhibition and differentiation induced by peroxisome proliferator activated receptor gamma ligand rosiglitazone in human melanoma cell line A375. Med Oncol. 2006;23(3):393-402.

46. Chon S-H, Tannahill R, Yao X, Southall MD, Pappas A. Keratinocyte differentiation and upregulation of ceramide synthesis induced by an oat lipid extract via the activation of PPAR pathways. Exp Dermatol. 2015;24(4):290-295.

47. Schütz R, Rawlings AV, Wandeler E, et al. Bio-derived hydroxystearic acid ameliorates skin age spots and conspicuous pores. Int J Cosmet Sci. 2019;41(3):240-256.

48. Rivier M, Castiel I, Michel S, et al. Peroxisome proliferator-activated receptor-alpha enhances lipid metabolism in a skin equivalent model. J Invest Dermatol. 2000;114:681-687.

49. Takeda S, Shimoda H, Takarada T, et al. Strawberry seed extract and its major component, tiliroside, promote ceramide synthesis in the stratum corneum of human epidermal equivalents. PLoS One. 2018;13(10):e020561.

50. Forman BM, Tontonoz P, Chen J, Brun RP, Spiegelman BM, Evans RM. 15-Deoxy-delta 12, 14-prostaglandin J2 is a ligand for the adipocyte determination factor PPAR gamma. Cell. 1995;83 (5):803-812.
51. Forman BM, Chen J, Evans RM. Hypolipidemic drugs, polyunsaturated fatty acids, and eicosanoids are ligands for peroxisome proliferator-activated receptors alpha and delta. Proc Natl Acad Sci U S A. 1997;94(9):4312-4317.

52. Moya-Camarena SY, Vanden Heuvel JP, Blanchard SG, Leesnitzer LA, Belury MA. Conjugated linoleic acid is a potent naturally occurring ligand and activator of PPARalpha. $J$ Lipid Res. 1999;40(8):1426-1433.

53. Zoete V, Grosdidier A, Michielin O. Peroxisome proliferator-activated receptor structures: ligand specificity, molecular switch and interactions with regulators. Biochim Biophys Acta. 2007;1771(8):915-925.

54. Shang J, Brust R, Mosure SA, et al. Cooperative cobinding of synthetic and natural ligands to the nuclear receptor $\operatorname{PPAR} \gamma$. Elife. 2018;7:e43320.

55. Yamamoto Y, Takei K, Arulmozhiraja S, et al. Molecular association model of PPAR $\alpha$ and its new specific and efficient ligand, pemafibrate: structural basis for SPPARM $\alpha$. Biochem Biophys Res Commun. 2018;499(2):239-245.

56. Ohtera A, Miyamae Y, Yoshida K, et al. Identification of a new type of covalent PPAR $\gamma$ agonist using a ligand-linking strategy. ACS Chem Biol. 2015;10(12):2794-2804.

57. Kuwabara N, Oyama T, Tomioka D, et al. Peroxisome proliferator-activated receptors (PPARs) have multiple binding points that accommodate ligands in various conformations: phenylpropanoic acid-type PPAR ligands bind to PPAR in different conformations, depending on the subtype. J Med Chem. 2012;55 (2):893-902.

58. Rimando AM, Nagmani R, Feller DR, Yokoyama W. Pterostilbene, a new agonist for the peroxisome proliferator-activated receptor alpha-isoform, lowers plasma lipoproteins and cholesterol in hypercholesterolemic hamsters. J Agric Food Chem. 2005;53 (9):3403-3407.

59. Bais AJ, Murphy PJ, Dry IB. The molecular regulation of stilbene phytoalexin biosynthesis in Vitis vinifera during grape berry development. Funct Plant Biol. 2000;27(5):425-433.

60. Li G, Singh A, Liu Y, Sunderland B, Li D. Comparative effects of sandalwood seed oil on fatty acid profiles and inflammatory factors in rats. Lipids. 2013;48(2):105-113.

61. Moy RL, Levenson C. Sandalwood album oil as a botanical therapeutic in dermatology. J Clin Aesthet Dermatol. 2017;10(10):34-39.

62. Dwivedi C, Abu-Ghazaleh A. Chemopreventive effects of sandalwood oil on skin papillomas in mice. Eur J Cancer Prev. 1997;6 (4):399-401.

63. Nugteren DH, Christ-Hazelhof E. Naturally occurring conjugated octadecatrienoic acids are strong inhibitors of prostaglandin biosynthesis. Prostaglandins. 1987;33(3):403-417.

64. Roupe KA, Remsberg CM, Yáñez JA, Davies NM. Pharmacometrics of stilbenes: seguing towards the clinic. Curr Clin Pharmacol. 2006;1 (1):81-101.

65. Sierra ML, Beneton V, Boullay A-B, et al. Substituted 2-[(4-aminomethyl)phenoxy]-2-methylpropionic acid PPARalpha agonists. 1. Discovery of a novel series of potent HDLc raising agents. J Med Chem. 2007;50(4):685-695.

66. Ayala A, Muñoz MF, Argüelles S. Lipid peroxidation: production, metabolism, and signaling mechanisms of malondialdehyde and 4-Hydroxy-2-nonenal. Oxid Med Cell Longev. 2014; 2014:360438.

67. Wiechers JW, Rawlings AV, Garcia C, et al. A new mechanism of action for skin whitening agents: binding to the peroxisome proliferator-activated receptor. Int $J$ Cosmet Sci. 2005;27(2): $123-132$.

68. Demento S, Dobkowski B, Pehratovic H, et al. Improving the quality of skin barrier function with PPAR-activating technology. J Am Acad Dermatol. 2014;70:AB64-AB64.

69. Oh I, Strong C. The molecular revolution in cutaneous biology: EDC and locus control. J Invest Dermatol. 2017;137(5):e101-e104. 
70. Mizutani Y, Sun H, Ohno Y, et al. Cooperative synthesis of ultra long-chain fatty acid and ceramide during keratinocyte differentiation. PLoS One. 2013;8(6):e67317.

71. Goleva E, Berdyshev E, Leung DYM. Epithelial barrier repair and prevention of allergy. J Clin Invest. 2019;129(4):1463-1474.

72. Wang Z, Man M, Li T, Elias PM, Mauro TM. Aging-associated alterations in epidermal function and their clinical significance. Aging. 2020;12:5551-5565.
73. Softa M, Giuseppe P, Stéphanie A, Laurent P, Bony P, Elian L. Seaberry (Hippophae rhamnoides L.) and water lily (Nymphaeaceae) extracts protect human skin against blue light, environmental pollutants and UV-A irradiations in an ex vivo model system. J Cosmetics Dermatol Sci Appl. 2019;9:244-262.

74. Zhang Q, Flach C, Mendelsohn R, et al. Topically applied ceramide accumulates in skin glyphs. Clin Cosmet Investig Dermatol. 2015;8:329-337.

\section{Publish your work in this journal}

Clinical, Cosmetic and Investigational Dermatology is an international, peer-reviewed, open access, online journal that focuses on the latest clinical and experimental research in all aspects of skin disease and cosmetic interventions. This journal is indexed on CAS
The manuscript management system is completely online and includes a very quick and fair peer-review system, which is all easy to use. Visit http://www.dovepress.com/testimonials.php to read real quotes from published authors. 